\title{
Seismic evidence of Alpine crustal thickening and wedging from the western Pyrenees to the Cantabrian Mountains (north Iberia)
}

\author{
D. Pedreira and J. A. Pulgar \\ Departamento de Geología, Universidad de Oviedo, Oviedo, Spain \\ J. Gallart and J. Díaz \\ Departament de Geofísica, Institut de Ciències de la Terra Jaume Almera, Consejo Superior de Investigaciones Científicas, \\ Barcelona, Spain
}

Received 24 November 2001; revised 3 July 2002; accepted 17 October 2002; published 18 April 2003.

[1] The Alpine collision between the Iberian and European plates resulted in a complex crustal structure beneath the northern Iberian Peninsula, as revealed from a new set of seismic refraction/wide-angle reflection profiles. The study area is characterized by two major E-W ranges, the Cantabrian Mountains and the Pyrenees, which are relayed to the south by the Iberian Chain. Important variations in crustal thickness and velocity distribution are found in a 560-km-long E-W transect. In contrast to the typical 30- to 32-km-thick European Variscan crust of the western end of the profile, a continuous Alpine crustal root is evidenced from the Cantabrian Mountains to the central Pyrenees, with a Moho depth of 46-48 km, locally rising to $40 \mathrm{~km}$ depth in between, beneath the Basque-Cantabrian Basin. Another outstanding feature is the inferred presence of high velocities of $6.40-6.75 \mathrm{~km} / \mathrm{s}$ at midcrustal depths, which can be associated with portions of a lower crustal wedge from the northern (European) domain indenting the southern (Iberian) crust during the Alpine stage of compression. This indentation produces the delamination of the Iberian crust, with northward underthrusting of its lower half and the consequent crustal thickening. The indenting wedge has a discontinuous presence along the longitudinal section, as it was controlled and/or affected by N-S to NE-SW structures. Further evidence of the northward subduction of the Iberian plate is provided by another profile toward the Aquitaine Basin, while a N-S profile across the Iberian Chain reveals an Alpine midcrustal thickening beneath this belt with Moho depths of $\sim 42 \mathrm{~km}$. INDEX TERMS: 7205 Seismology: Continental crust (1242); 8102 Tectonophysics: Continental contractional orogenic belts; 8105 Tectonophysics: Continental margins and sedimentary basins; 9335 Information Related to Geographic Region: Europe; KEYWORDS: Pyrenees, Basque-Cantabrian Basin, Cantabrian Mountains, Alpine orogeny, crustal wedges, seismic refraction

Citation: Pedreira, D., J. A. Pulgar, J. Gallart, and J. Díaz, Seismic evidence of Alpine crustal thickening and wedging from the western Pyrenees to the Cantabrian Mountains (north Iberia), J. Geophys. Res., 108(B4), 2204, doi:10.1029/2001JB001667, 2003.

\section{Introduction}

[2] The present mountain chains in the Iberian Peninsula are the topographic expression of the tectonic collision between the European, Iberian, and African plates in Tertiary times. Two intraplate mountain chains resulted from the uplift of basement blocks, the Iberian Chain and the Central System, but the major topographic features were formed at the boundaries of the Iberian plate: the Betic Cordillera in the south and the Pyrenees and its western prolongation, the Cantabrian Mountains, in the north (Figure 1).

[3] The acquisition in the mid-1980s of the Etude Continentale et Océanique par Reflexion et Refraction Sismique

Copyright 2003 by the American Geophysical Union. 0148-0227/03/2001JB001667\$09.00
(ECORS)-Pyrenees seismic reflection profile [Etude Continentale et Océanique par Reflexion et Refraction Sismique (ECORS) Pyrenees Team, 1988] revealed the complex deep structure of this mountain chain, with the thinner European plate indenting into the thicker Iberian one, forcing the Iberian plate's subduction to the north and the formation of a doubly-vergent wedge at upper crustal to midcrustal levels [e.g., Choukroune and ECORS Team, 1989; Muñoz, 1992].

[4] In the early 1990s an extensive seismic survey (Seismic Study of the North Iberian Crust (ESCIN) project) was carried out in the Cantabrian Mountains and the Cantabrian continental margin (the southern border of the Bay of Biscay). The results of ESCIN and related projects, including seismic reflection, refraction, wide-angle, and gravity measurements, clearly revealed the presence of an Alpine crustal root beneath the Cantabrian Mountains, with the northward 


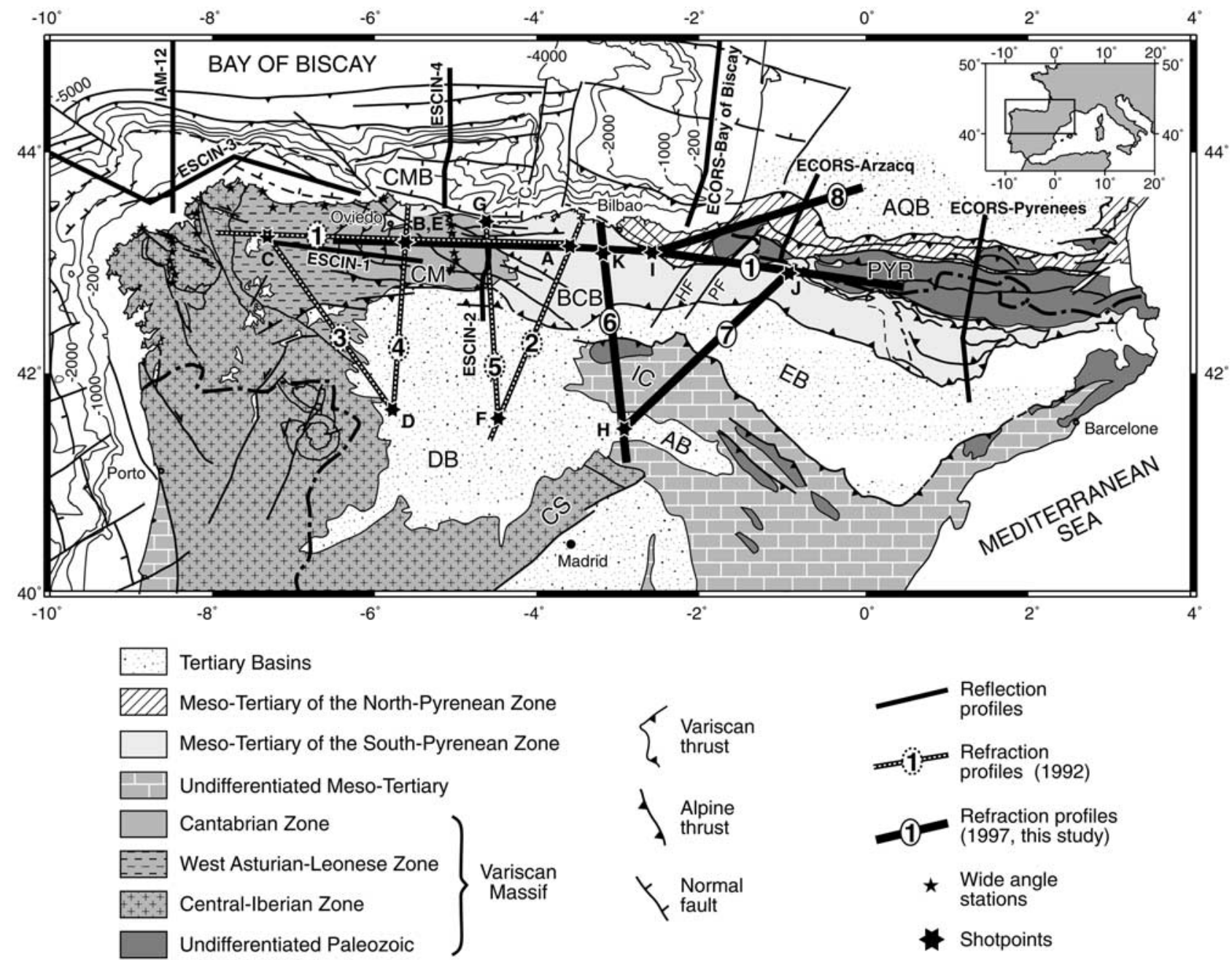

Figure 1. Tectonic map of northern Iberia showing the location of the seismic profiles studied in this paper (thick lines). Reflection profiles from the Etude Continentale et Océanique par Reflexion et Refraction Sismique (ECORS), Seismic Study of the North Iberian Crust (ESCIN), and Iberian Atlantic Margin projects are shown as thin lines. Previous refraction profiles in the Cantabrian Mountains [Fernández-Viejo et al., 2000] are represented as dotted lines. AB, Almazán Basin; AQB, Aquitaine Basin; BCB, Basque-Cantabrian Basin; CM, Cantabrian Mountains; CMB, Cantabrian Margin Basin; CS, Central System; DB, Duero Basin; EB, Ebro Basin; HF, Hendaya Fault; IC, Iberian Chain; PF, Pamplona Fault; PYR, Pyrenees; TC, Torrelavega Canyon.

subduction of the Iberian crust down to at least $55 \mathrm{~km}$ depth [Pulgar et al., 1996, 1997; Gallart et al., 1997; FernándezViejo et al., 1998, 2000].

[5] The good knowledge of the deep crustal structure of these mountain chains was in contrast with the poor geophysical information available for the area located in between, the Basque-Cantabrian Basin. However, this area of lower relief, where the Mesozoic extension associated with the opening of the Bay of Biscay was mainly focused, appeared as a key element to a global understanding of the crustal structure and tectonic evolution of northern Iberia.

[6] A seismic survey carried out in the summer of 1997 was designed to overcome this lack of information and to establish the deep crustal structures beneath the thick sedimentary cover of the Basque-Cantabrian Basin, the link between the Pyrenees and Cantabrian Mountains, as well as to establish the relation of these structures to the ones observed along the continental margin. The experiment consisted of four seismic refraction/wide-angle reflection profiles (Figure 1): an E-W profile from the Cantabrian Mountains to the west central Pyrenees, a WSW-ENE profile crossing the western end of the Pyrenees from the Basque-Cantabrian Basin to the Aquitaine Basin, and two profiles, N-S and NE-SW-oriented, that cut across the Iberian Chain. In this paper we present the seismic data, the velocity-depth models obtained, and their geological interpretations and tectonic implications.

\section{Tectonic Setting}

[7] The area of the northern Iberian Peninsula that was investigated shows a complex three-dimensional geological structure attained through three main tectonic events.

1. The oldest extensively recognized event is the Variscan orogeny. It resulted from the collision between the Laurentia and the continental margin of Gondwana at 

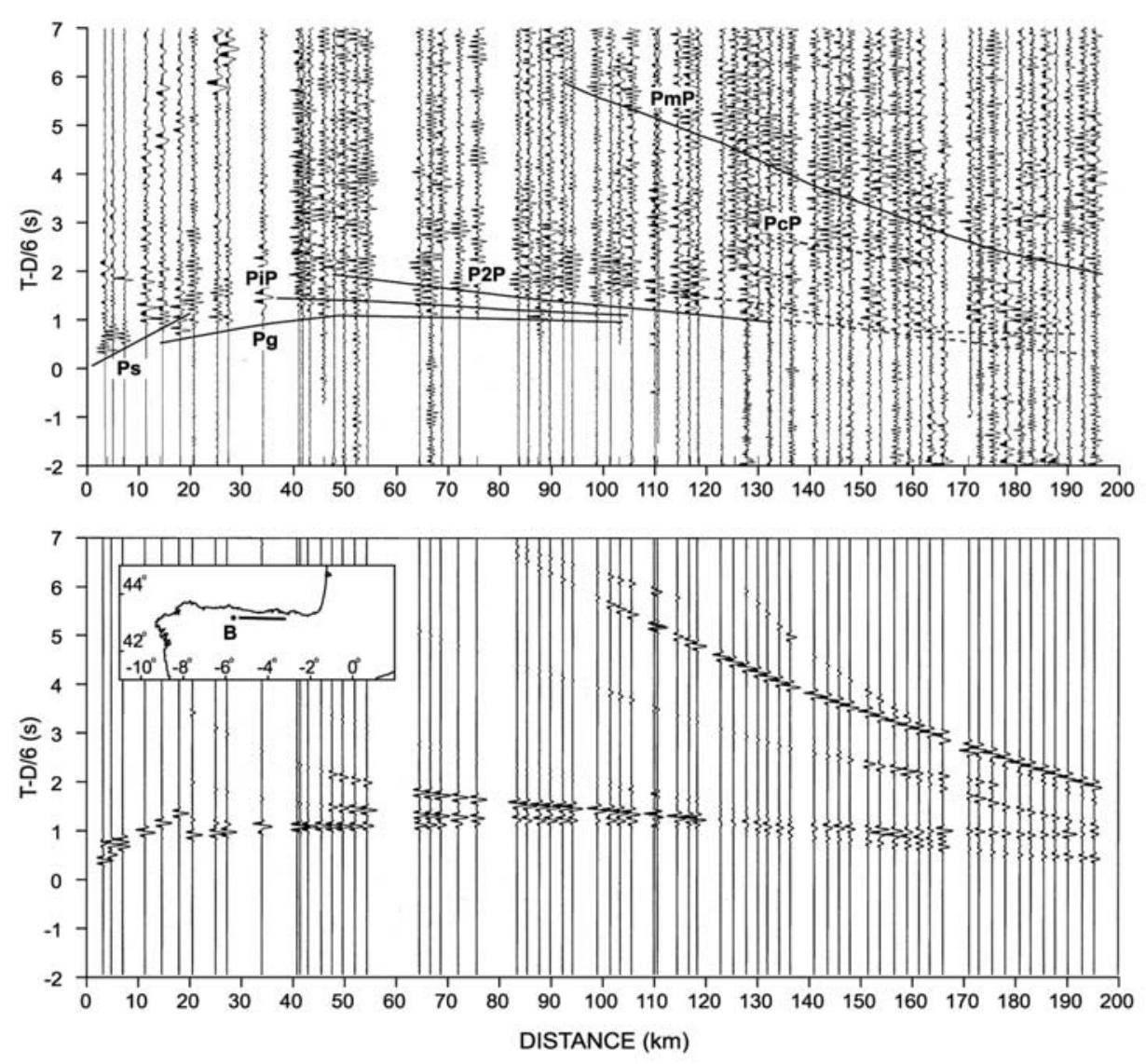

Figure 2. Shot B recorded toward the east along profile 1. (top) Record section with velocity reduction of $6 \mathrm{~km} / \mathrm{s}$ and 3- to $15-\mathrm{Hz}$ band-pass filter. Phase labels are explained in the text. (bottom) Synthetic section obtained from the velocity-depth model of Figure 5.

the end of the Carboniferous [e.g., Matte, 1991; PérezEstaun et al., 1991]. The geological trends of this orogen show an arched pattern in this area (Ibero-Armorican arch), with a general tectonic movement toward the east in the Cantabrian Mountains and toward the south in the Pyrenean Axial Zone [Parga Pondal, 1982; Julivert and Martínez, 1983; Pérez-Estaún et al., 1991]. The Cantabrian Mountains are located mostly within the so-called Cantabrian Zone [Julivert et al., 1974], which is the most external area of the Variscan orogen in northern Spain, characterized by a thin-skinned tectonic deformation style with extensive development of folds and thrusts and scarce magmatic and metamorphic phenomena. The hinterland zone (Central Iberian Zone) is located to the west, with a broad transitional area, the Westasturian-Leonese Zone, in which shot point $\mathrm{C}$ in Figure 1 is located. The Paleozoic rocks of the Pyrenean Axial Zone are mainly metamorphic and magmatic, probably representing the continuation of the Westasturian-Leonese Zone along the northern branch of the Ibero-Armorican arch [Julivert and Martínez, 1983; Julivert, 1996]. Another small outcrop of metamorphic Paleozoic rocks, located in the area investigated in this paper, is found in the northern Iberian Chain (La Demanda massif). This outcrop also shows stratigraphic, structural, and metamorphic affinities with the rocks of the Westasturian-Leonese Zone, constituting its prolongation through the southern branch of the arch.
2. The next regional event is the Mesozoic crustal extension related to the opening of the North Atlantic. After the Variscan orogeny a rifting episode took place, giving rise to a wide Permo-Triassic basin [Martínez-García, 1983; Lepvrier and Martinez-Garcia, 1990]. This was followed by an important period of crustal extension related to the opening of the North Atlantic Ocean and the Bay of Biscay. The regional direction of extension was approximately N-S, giving rise to the individualization of the Iberian Peninsula as a subplate and the formation of important Mesozoic sedimentary basins, such as the Basque-Cantabrian Basin and its offshore prolongation along the Cantabrian continental margin (Figure 1). The Mesozoic rifting began in the Late Jurassic with the fracturing of the continental platform and the creation of Lower Cretaceous grabens. During the Aptian-Albian, extension increased, leading to the formation of complex sedimentary systems in horst and grabens, with rotation of blocks along listric faults [Rat, 1988; GarciaMondéjar, 1989]. Most of the Cretaceous continental extension took place in a regional transtensional regime related to the left-lateral drift of the Iberian Peninsula along the North Pyrenean Fault zone. In this context, extrusion of volcanic rocks and the appearance of a high-temperature/ low-pressure metamorphic event took place at 85-110 Ma in a narrow band close to the North Pyrenean Fault [Albarède and Michard-Vitrac, 1978; Montigny et al., 1986; Golberg and Maluski, 1988]. In the Basque-Cantabrian Basin, 


\section{$\mathbf{W}$}

DISTANCE $(\mathrm{km})$

$\mathbf{E}$

(a)

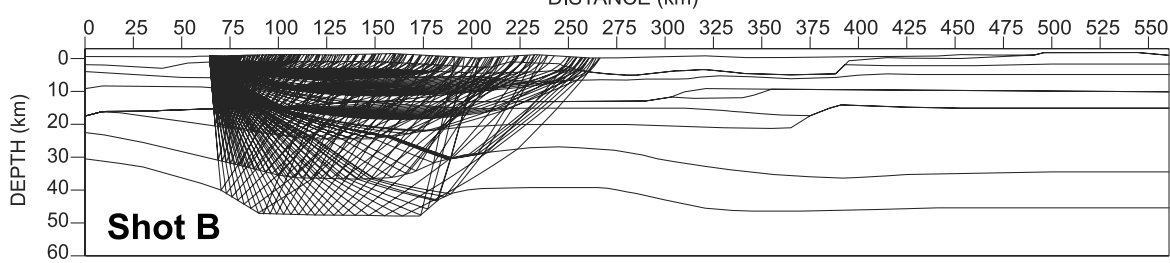

可

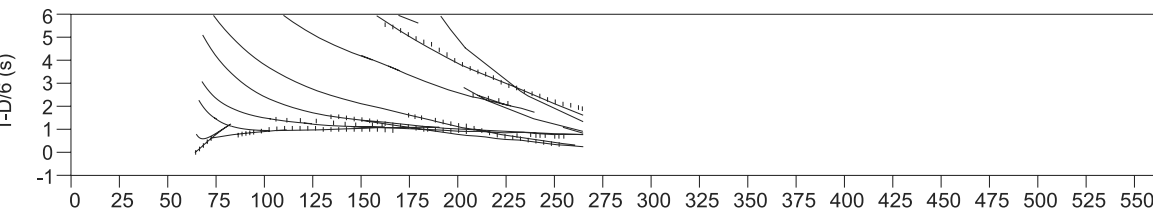
DISTANCE $(\mathrm{km})$

(b)
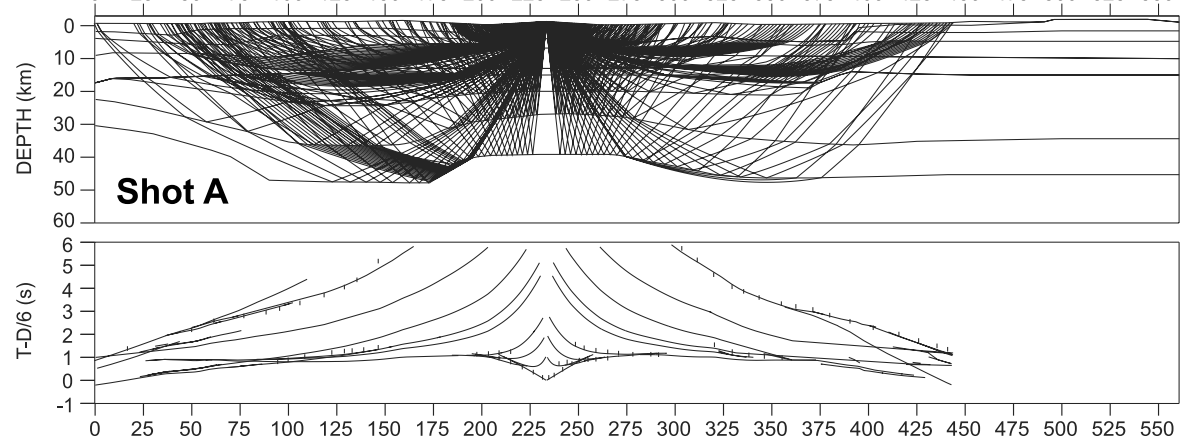

DISTANCE $(\mathrm{km})$

(C)
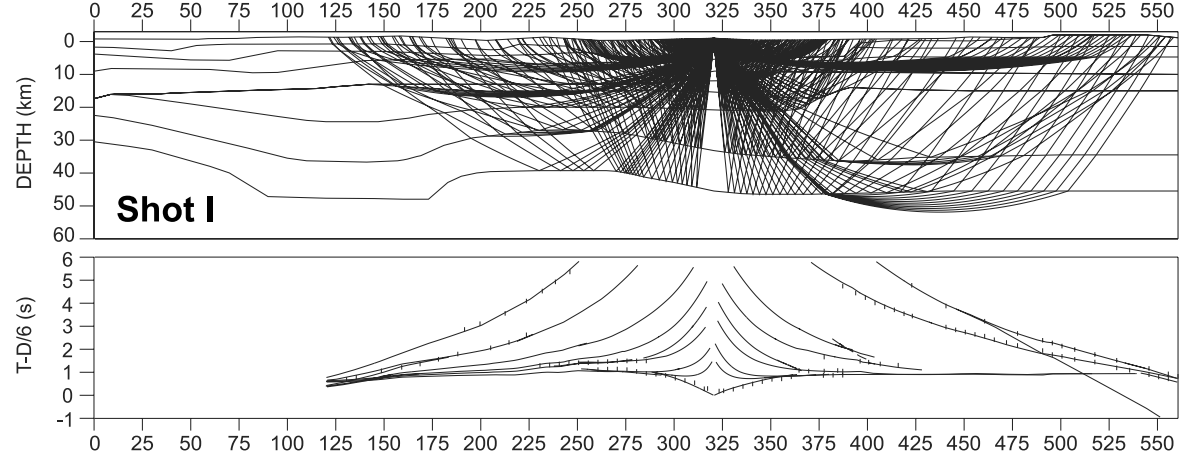

DISTANCE $(\mathrm{km})$

(d)

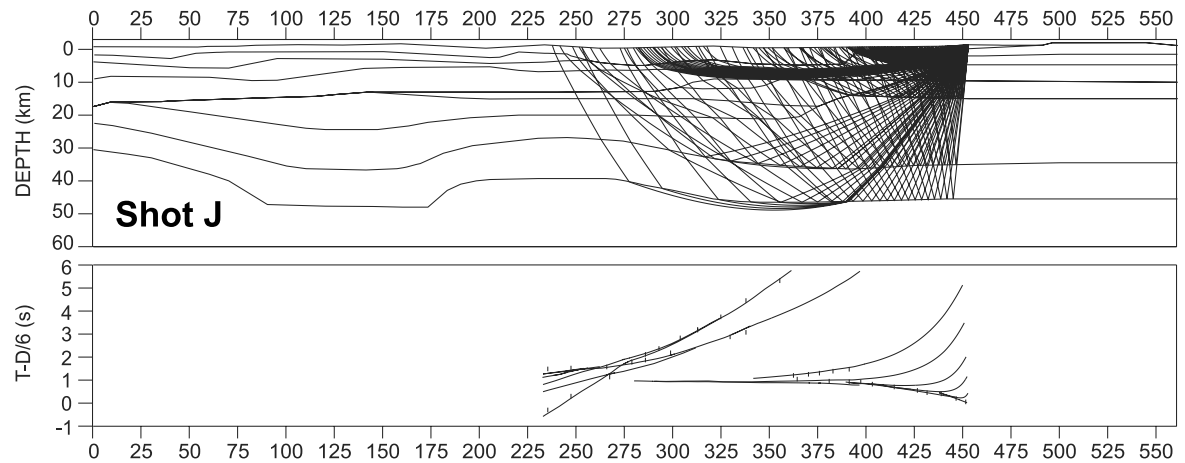

Figure 3. Ray tracing and fitting between observed (short vertical lines) and calculated (solid lines) travel times along profile 1 for (a) shot B to the east, (b) shot A, (c) shot I, and (d) shot J to the west. All the reflected and diving rays and arrivals are shown. The velocity-depth model used is illustrated in Figure 5. 


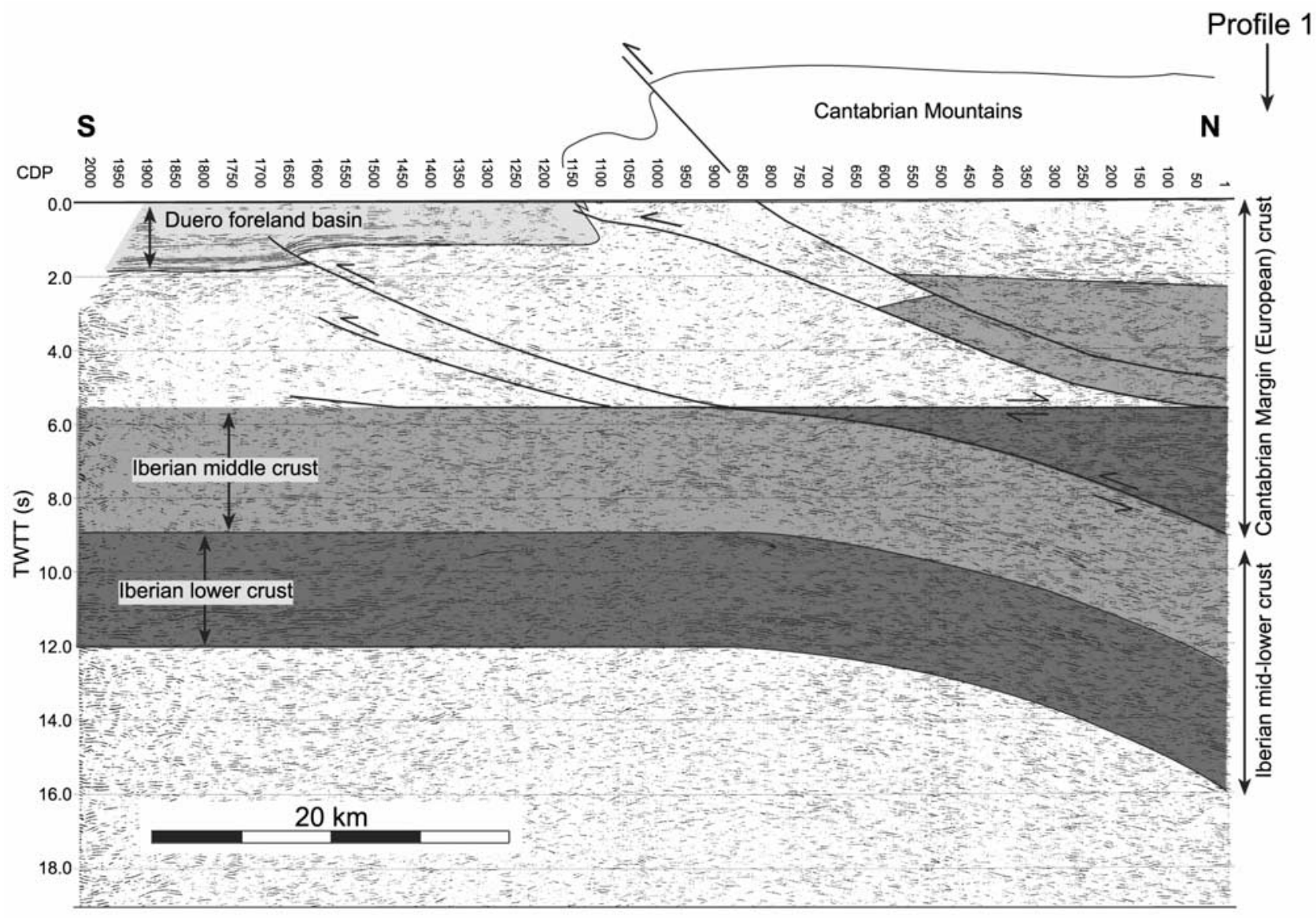

Figure 4. Interpreted coherency-filtered section of unmigrated ESCIN-2 profile showing the Alpine duplication of the crust under the Cantabrian Mountains and the northward subduction of the Iberian crust under the Cantabrian Margin crust [after Pulgar et al., 1997; Gallastegui, 2000].

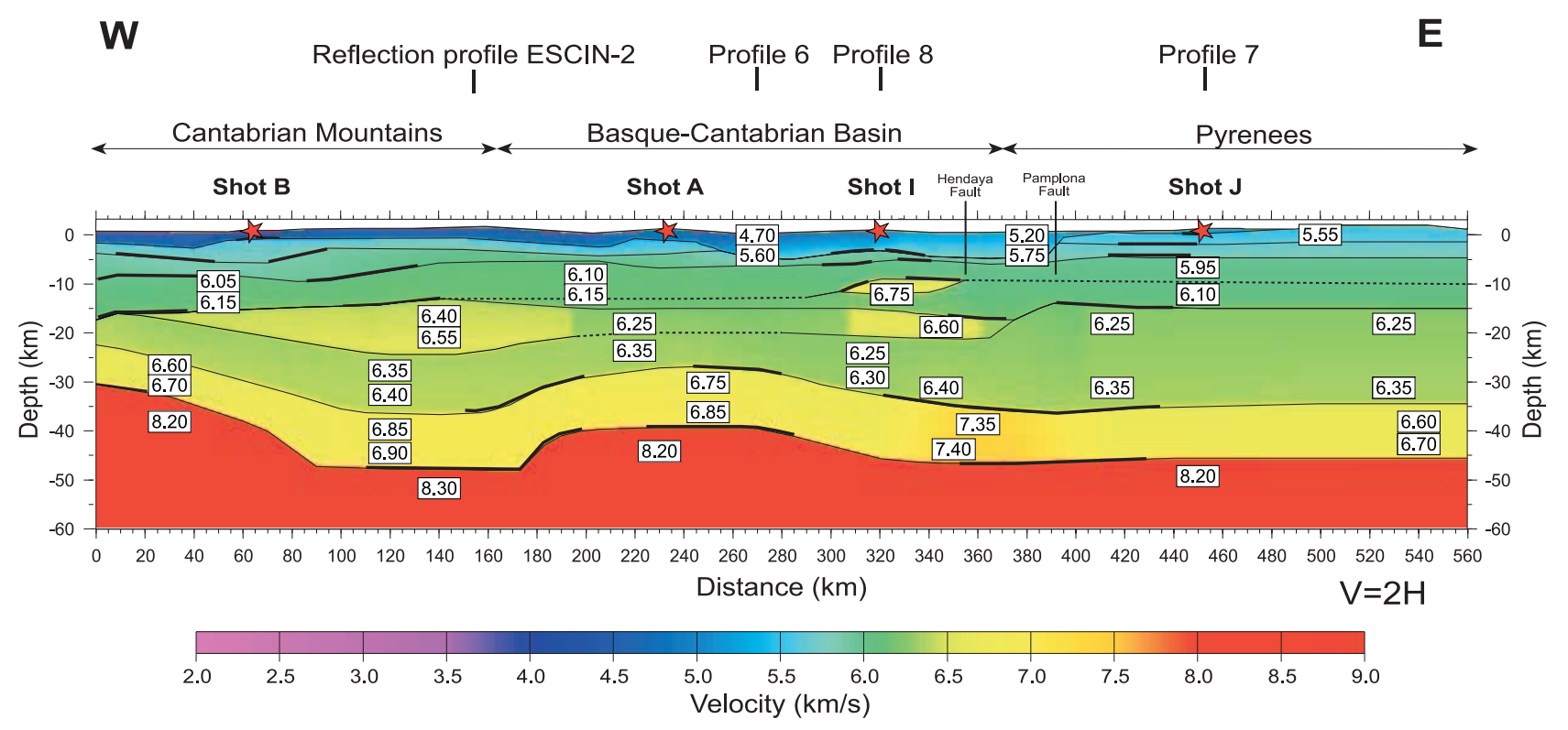

Figure 5. Velocity-depth model obtained for profile 1, showing the geological zones crossed and its intersection points with profiles 6,7 , and 8 . Numbers in white boxes indicate representative velocities $\left(\mathrm{km} \mathrm{s}^{-1}\right)$. Dashed lines indicate surfaces with no velocity contrast. Bold lines indicate layer segments directly sampled by seismic reflections. The structure to the west of shot point B has been obtained by modeling shot $\mathrm{B}$ to the west and shot $\mathrm{C}$ to the east (not included in this paper) in order to join this new segment of the E-W transect with the earlier profile of Fernández-Viejo et al. [2000]. See Figure 1 for location. 

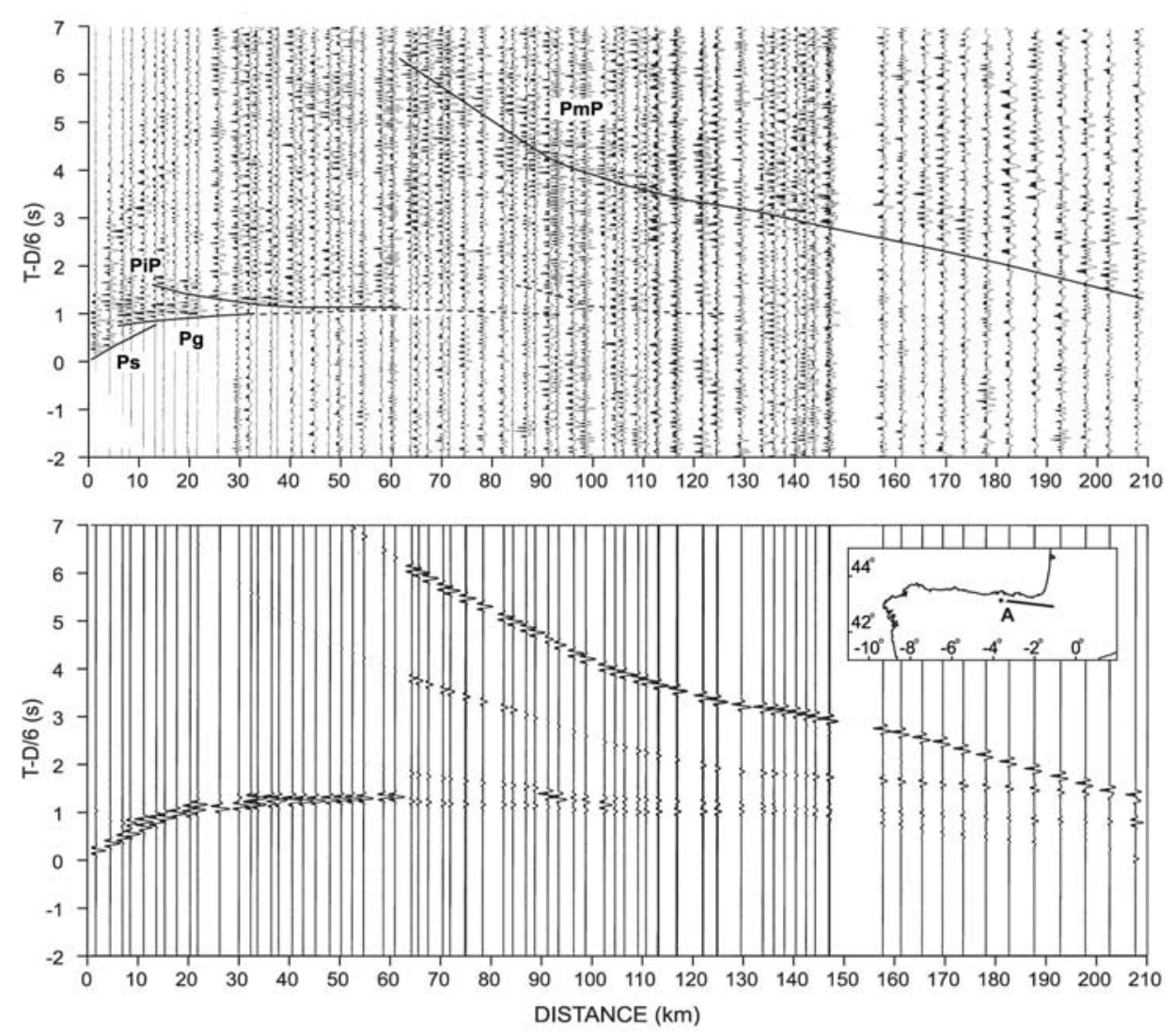

Figure 6. Shot A recorded toward the east along profile 1. (top) Record section. (bottom) Synthetic section from the velocity-depth model of Figure 5.

extension of the crust reached a maximum during this period with the occurrence of submarine volcanism but without oceanization. In the Late Cretaceous a long period of regional subsidence took place before the closing of the Basque-Cantabrian Basin and the reactivation of structures during the Pyrenean collision. The Basque-Cantabrian Basin is limited to the west by the Paleozoic outcrops of the Cantabrian Zone and extends to the north along the Cantabrian continental margin. Its eastern limit is usually placed at the Pamplona Fault (Figure 1), a NE-SW striking vertical and deep structure, which played an important role in controlling the Mesozoic sedimentation; more than $5 \mathrm{~km}$ of sediments of this age are found to the west, while only a few hundred meters are located to the east.

3. Finally, the Alpine stage of compression constitutes the most recent tectonic event in the area. Convergence between the Iberian and European plates gave rise to the closing of the Mesozoic basins and the formation of the Pyrenees, with the northward subduction of the Iberian crust beneath the European one [Choukroune and ECORS Team, 1989]. The deformation is not coeval along strike, migrating toward the west. It began in the Late Cretaceous in the eastern Pyrenees [Vergés et al., 1995], when subsidence was still taking place in the Basque-Cantabrian Basin. The main stage of orogenic growth in the eastern Pyrenees, with widespread continental sedimentation in the Ebro Basin, began in the mid to late Eocene [Vergés et al., 1995] and coincided with the onset of deformation in the Cantabrian continental margin [Álvarez-Marrón et al., 1997]. The southern branch of the belt migrated through the BasqueCantabrian Basin to the actual Cantabrian Mountains, which were uplifted in Eocene to Miocene times along a south directed thrust developed in the Paleozoic basement [Alonso et al., 1996] and clearly imaged in the ESCIN-2 deep seismic reflection line [Pulgar et al., 1996, 1997].

\section{Data Acquisition, Processing, and Modeling Procedure}

[8] The field experiment was carried out in the summer of 1997. Nine land shots were distributed in five locations (A, I, J, H, and $\mathrm{K}$ in Figure 1), with $\sim 1500 \mathrm{~kg}$ of explosives in each shot. Data were recorded in three components by a total of 100 digital portable stations (40 stations from Spanish institutions, 40 from the Incorporated Research Institutions for Seismology (IRIS)-Program for Array Seismic Studies of the Continental Lithosphere (PASSCAL) consortium, 10 from the Instituto de Ciências da Terra e do Espaço, Lisbon, Portugal, and 10 from the Swiss Federal Institute of Technology-Eidgenössische Technische Hochschule, Zurich, Switzerland), with a station spacing of $\sim 2.5$ $\mathrm{km}$. Four profiles were acquired (Figure 1):

1. Profile 1 is E-W oriented and $560 \mathrm{~km}$ long. It constitutes the prolongation toward the east of a previous profile acquired in 1992 [Fernández-Viejo et al., 2000] (Figure 1). A failure in the recording of shot A in 1992, at the eastern end of this earlier profile, led us to consider an important overlap in the acquisition of the new segment. Shot A was fired again, 

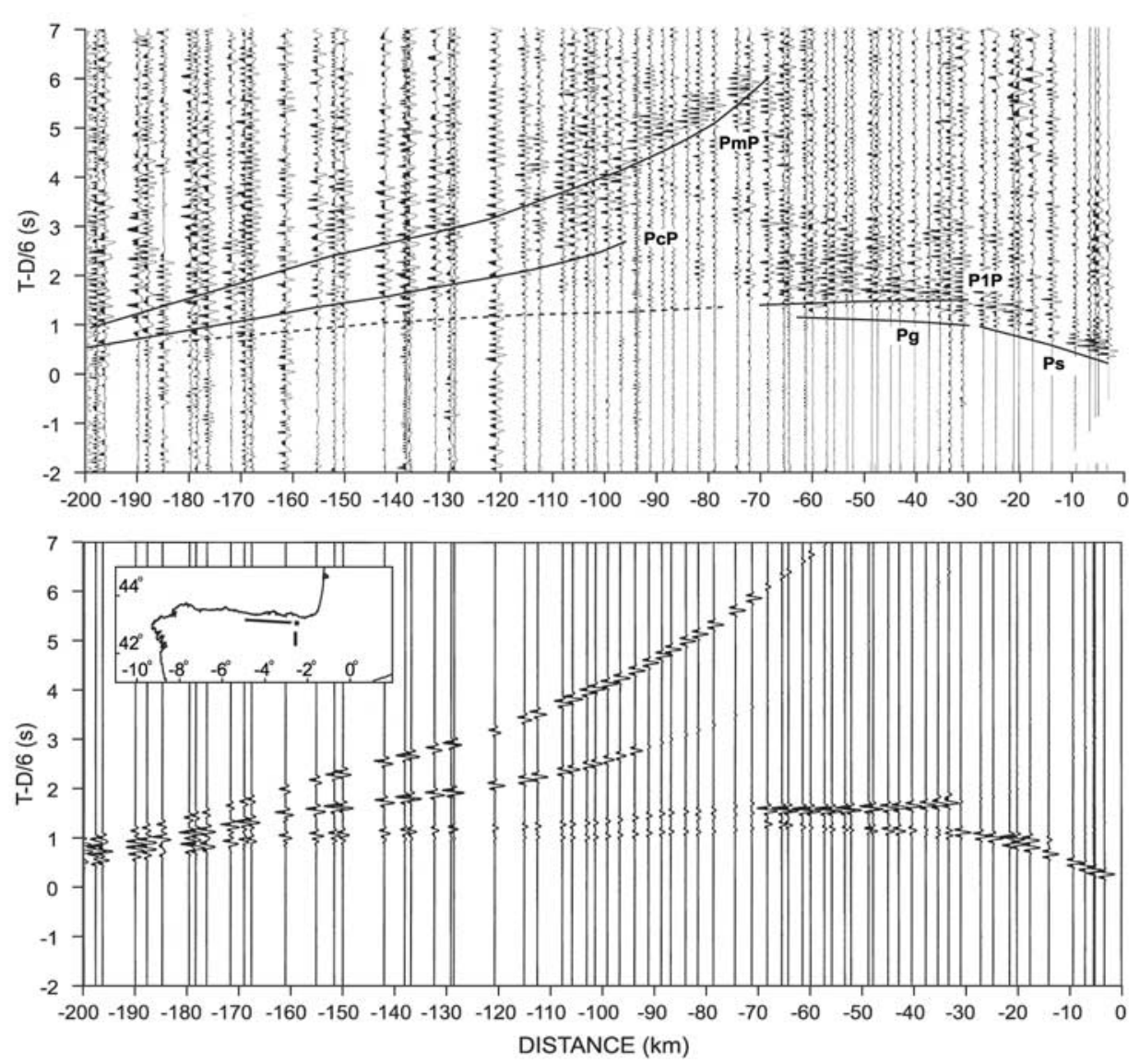

Figure 7. Shot I recorded toward the west along profile 1. (top) Record section. (bottom) Synthetic section from the velocity-depth model of Figure 5.

in addition to new shots at positions I and J. Two explosions were made in each location and were recorded in both directions with the exception of the explosions in position $\mathrm{J}$, which were recorded only to the west. This profile runs across strike with respect to the Variscan trends in its western half and along strike with respect to the main Alpine trends of North Iberia.

2. Profile 8 is WSW-ENE directed and $200 \mathrm{~km}$ long. It is an unreversed profile, recorded from shot point I and intended to map the transition between the Iberian and European plates from the Basque-Cantabrian Basin to the Aquitaine Basin in France, crossing the western end of the Pyrenees.

3. Profile 6 is N-S oriented and $260 \mathrm{~km}$ long. It was recorded from two shots near the ends ( $\mathrm{H}$ and $\mathrm{K}$ in Figure 1). The aim of this profile was to control the crustal structure in a N-S direction, perpendicular to the Alpine trends, from the Basque-Cantabrian Basin to the Iberian Chain.

4. Profile 7 is NE-SW oriented and $220 \mathrm{~km}$ long. This is an unreversed profile recorded from shot point $\mathrm{J}$ and aimed to map the change in crustal structure from the Iberian Chain to the western Pyrenees and across the Ebro Basin.

[9] The collected seismic data have been processed to create files in SEG-Y format and are presented here as conventional record sections, with $3-$ to $15-\mathrm{Hz}$ band-pass filters, trace-normalized amplitudes, and reduction velocities of 6 and $3.46 \mathrm{~km} / \mathrm{s}$ for vertical and horizontal compo- nents, respectively. Additional record sections with different filters and/or true amplitudes were used to help in the interpretation process.

[10] After identifying the different seismic phases on the record sections, the $P$ wave velocity-depth models were obtained by the forward modeling of travel times and amplitudes of diving and reflected waves using the software developed by Zelt and Smith [1992]. Additional geological and geophysical constraints including seismic reflection profiles were taken into account in the modeling procedure.

\section{Data Description and Interpretation}

[11] The usual nomenclature has been used to label the different seismic phases interpreted in the record sections: $P s, P g$, and $P n$ denote refractions through the near-surface material, the upper crust, and the upper mantle, respectively. $P i P, P c P$, and $P m P$ correspond with reflections produced at the top of the middle crust, at the top of the lower crust, and at the Moho discontinuity, respectively. Labels $P 1 P$ and $P 2 P$ denote particular reflections from complex structures at upper to midcrustal depths discussed in the text.

\subsection{East-West Transect From the Cantabrian Mountains to the West Central Pyrenees}

[12] The new segment of profile 1 recorded from shot points A, I, and J extends the E-W transect of Fernández- 

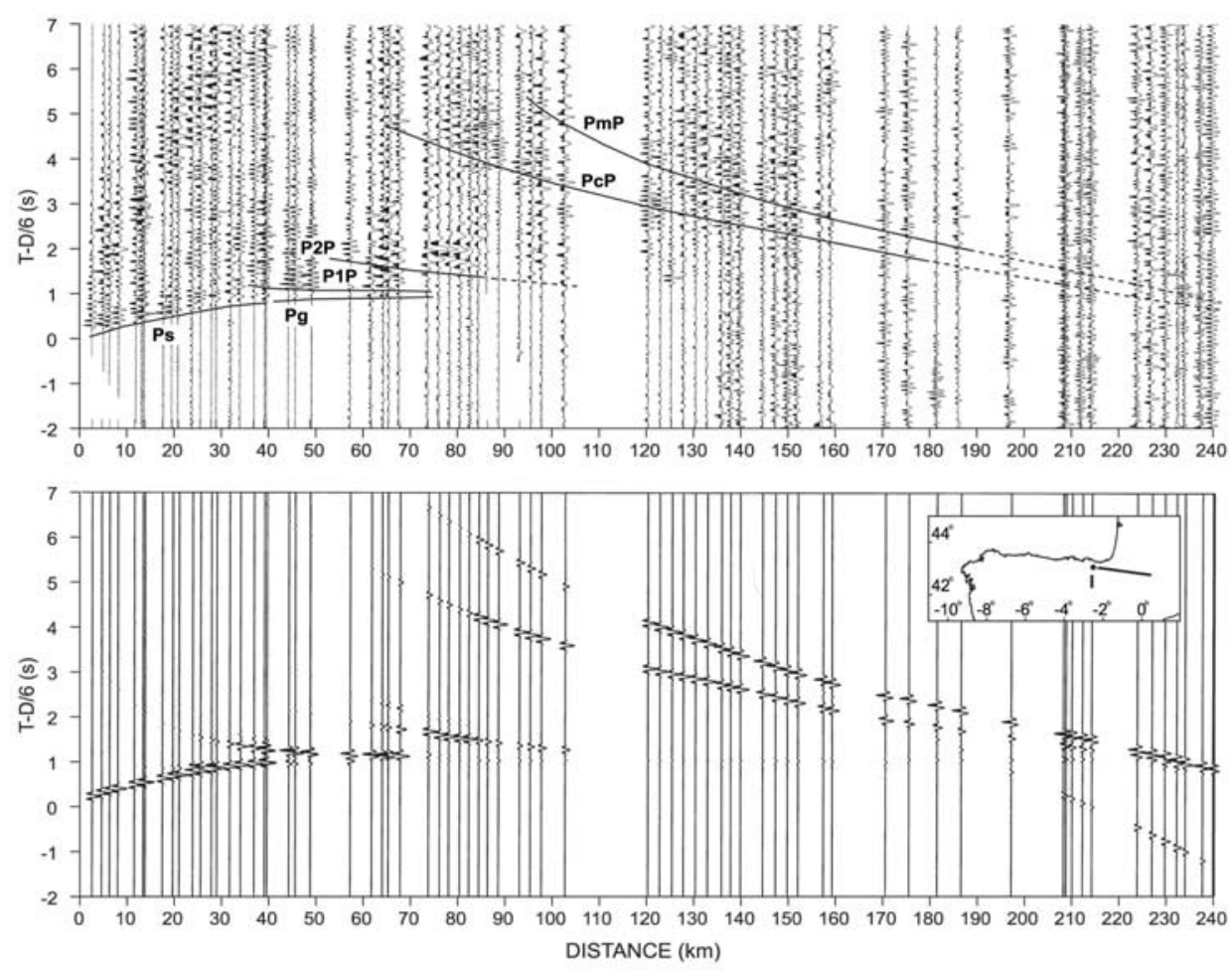

Figure 8. Shot I recorded toward the east along profile 1. (top) Record section. (bottom) Synthetic section from the velocity-depth model of Figure 5.

Viejo et al. [2000] for $\sim 325 \mathrm{~km}$ eastward. It is of particular relevance to establish here the extent of the crustal root evidenced by Fernández-Viejo et al. [2000] eastward of shot point $\mathrm{B}$, where the Moho depth reaches $45-48 \mathrm{~km}$ in contrast to $30-32 \mathrm{~km}$ depth westward of this point. Therefore the record section of shot B to the east, acquired in the previous project [Fernández-Viejo et al., 2000], has been included in the modeling process in order to join both segments of the transect.

\subsubsection{Retrieving the Deep Structure Beneath the Eastern Cantabrian Mountains: Evidence of a Crustal Imbrication}

[13] The data from shot $\mathrm{B}$ recorded to the east and their interpretation are presented in Figures 2 (record section and synthetic seismograms) and $3 \mathrm{a}$ (fitting of arrival times). The seismic phases are evaluated on the basis of work by Fernández-Viejo et al. [2000], and the basic modification concerns the interpretation of their $P^{*}$ phase (here called $P 2 P$ in Figure 2). The $P 2 P$ reflection can be observed from 50 to $130 \mathrm{~km}$, with particularly strong energy from $80 \mathrm{~km}$ onward. Fernández-Viejo et al. [2000] interpreted this energetic part of the arrival as the reflection in the basal detachment of the Cantabrian Zone imaged farther west by the ESCIN-1 reflection profile [Pérez-Estaún et al., 1994]. The strong arrivals of $P^{*}$ required a strong velocity contrast, and the body beneath the detachment level was characterized by a velocity of $6.45 \mathrm{~km} / \mathrm{s}$ in the model of FernándezViejo et al. [2000]. On the other hand, from $150 \mathrm{~km}$ onward, the first and low energetic arrivals between 0.5 and $1 \mathrm{~s}$ reduced time, were attributed in that model to the reflection at the top of the lower crust $(P c P)$. Note that the $P m P$ is a very late phase; hence that interpretation means that the lower crust to the east of shot point B would be unusually thick $(\sim 25 \mathrm{~km})$.

[14] A different interpretation of this $P 2 P$ reflection will be proposed here and is supported by the results of the ESCIN-2 reflection profile, which runs perpendicularly to this E-W transect and whose northern end lies exactly between shot points B and A (Figure 1). The ESCIN-2 profile (Figure 4) clearly images the northward deepening of the Iberian Moho beneath the Cantabrian Mountains [Pulgar et al., 1996, 1997]. The lower half of the Iberian crust is bent from the mountain front to the north beneath a wedgeshaped package of strong, subhorizontal reflectors, the top of which constitute a detachment level where the Alpine frontal thrust of the Cantabrian Mountains is rooted. According to several geophysical constraints, this wedge can be interpreted as the lower crust of the Cantabrian Margin (European domain) indenting into the Iberian crust and forcing its northward subduction: its reflectivity pattern is typical of the lower crust, it can be easily connected with the Cantabrian Margin lower crust imaged by multichannel processing of the wide-angle data recorded on the onshore prolongation of the ESCIN-4 reflection profile [Gallart et al., 1997], and, finally, the crustal root, well imaged seismically, does not show up as a minimum in the Bouguer anomaly map, suggesting that dense (lower crustal) material must be present in the thickened region [Fernández-Viejo et al., 1998; Pedreira, 1998; Gallastegui, 2000].

[15] The ESCIN-2 profile in Figure 4 is unmigrated, but forward modeling carried out by Gallastegui [2000] shows that this wedge of lower crustal material in the northern end of the ESCIN-2 profile is located at the same depth range as the anomalous body of high velocity in profile 1, on top of 
which the reflection $P 2 P$ is generated. Velocities of $6.40-$ $6.55 \mathrm{~km} / \mathrm{s}$ below $13-16 \mathrm{~km}$ depth have been used for this body in the model presented in this paper (Figure 5), in agreement with the value of $6.50 \mathrm{~km} / \mathrm{s}$ considered in the forward modeling of the ESCIN-2 profile [Gallastegui, 2000]. Beneath this longitudinal section of the wedge of lower crustal rocks from the Cantabrian Margin the thick lower crust modeled by Fernández-Viejo et al. [2000] has been divided into the Iberian middle and lower crusts sinking beneath the protruding wedge, as imaged in the ESCIN-2 reflection profile. The reflections from the top of the Iberian lower crust $(P c P)$ can be identified between the $P 2 P$ and the $P m P$ arrivals (labeled dashed line in Figure 2). Despite the strong velocity contrast at this interface (Figure 5), this phase shows a low energy that is appropriately expressed in the synthetic record section. The first low-energy arrivals at the end of the profile, between 0.5 and $1 \mathrm{~s}$, can be fitted as refractions through the wedge of high-velocity rocks. This wedge must end to the west of shot point $B$, where the crust shows its typical Variscan thickness of 30-32 km [Fernández-Viejo et al., 2000]. Further evidence concerning the presence of high-velocity materials at midcrustal levels is found in other seismic sections farther to the east and will be discussed in section 4.1.2.

\subsubsection{Lateral Variations of the Structure Beneath the Basque-Cantabrian Basin}

[16] Marked structural differences are inferred beneath the Basque-Cantabrian Basin, sampled from shots A (east and west) and I (west). Data from shot A exhibit a rather low signal-to-noise ratio, and only major features of the eastern record section will be discussed. There is no evidence in the western Basque-Cantabrian Basin of a high-velocity intracrustal body (compare energies after the $\mathrm{Pg}$ phase in the record sections from shot A to the east in Figure 6 and from shot B in the same direction in Figure 2). The $P m P$ arrival times from shot A reveal the presence of a flat Moho at 39-40 km depth, which extends for $\sim 50 \mathrm{~km}$ to both sides beneath shot point $A$ and then deepens up to 46$48 \mathrm{~km}$ (Figure 3b). Although the PmP phase in Figure 6 is very poor below $100 \mathrm{~km}$ distance, the horizontal record sections helped to extend the correlation down to at least $\sim 80 \mathrm{~km}$ distance. Further evidence for this local rise in the Moho is given by the record section of shot I to the west.

[17] Shot point I is located over the trace of the Biscay Anticlinorium, a major Alpine structure in the BasqueCantabrian Basin. In this area a marked positive gravity anomaly and the highest aeromagnetic anomaly of the Spanish mainland [Ardizone et al., 1989] are observed, both with a NW-SE orientation.

[18] Figure 7 shows the record section and synthetic seismograms for shot I recorded to the west, and Figure $3 \mathrm{c}$ shows the ray tracing and fitting of travel times. Ps can be correlated as the first arrival up to $30 \mathrm{~km}$ from the shot point, evidencing the great thickness of the Mesozoic and Tertiary deposits of the Basque-Cantabrian Basin. A vertical gradient between $4.70 \mathrm{~km} / \mathrm{s}$ at the surface and $5.60 \mathrm{~km} / \mathrm{s}$ for the well-compacted Mesozoic rocks at the base of the basin has been introduced in the model (Figure 5). The $P g$ phase can be identified at distances from 30 to $60 \mathrm{~km}$ with an apparent velocity of $5.8 \mathrm{~km} / \mathrm{s}$. The conspicuous reflected energy observed between offsets of 30 and $70 \mathrm{~km}(P 1 P$ in Figure 7$)$ is produced at only $10 \mathrm{~km}$ depth and requires a
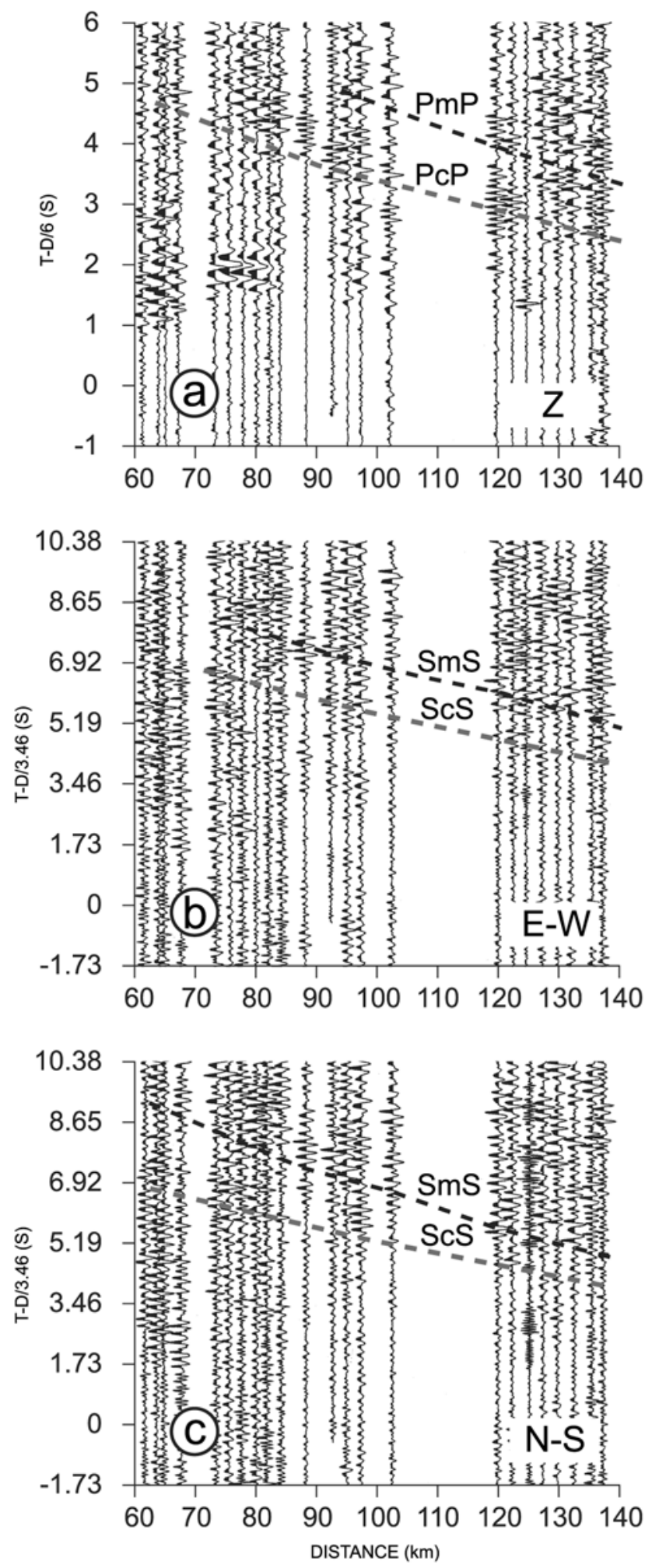

Figure 9. (a) Blowup of the $P$ section (vertical component, $V r=6 \mathrm{~km} / \mathrm{s}$ ) of shot I recorded toward the east along profile 1, showing the interpreted $P c P$ and $P m P$ phases. (b and c) Correlation of $S c S$ and $S m S$ phases in the corresponding $S$ sections (E-W and N-S components, respectively), with $V r=3.46 \mathrm{~km} / \mathrm{s}$ and with a $\sqrt{3}$ factor at the timescale relative to the $P$ section (so that the $P$ and $S$ phases can be compared for a standard crustal lithology). 

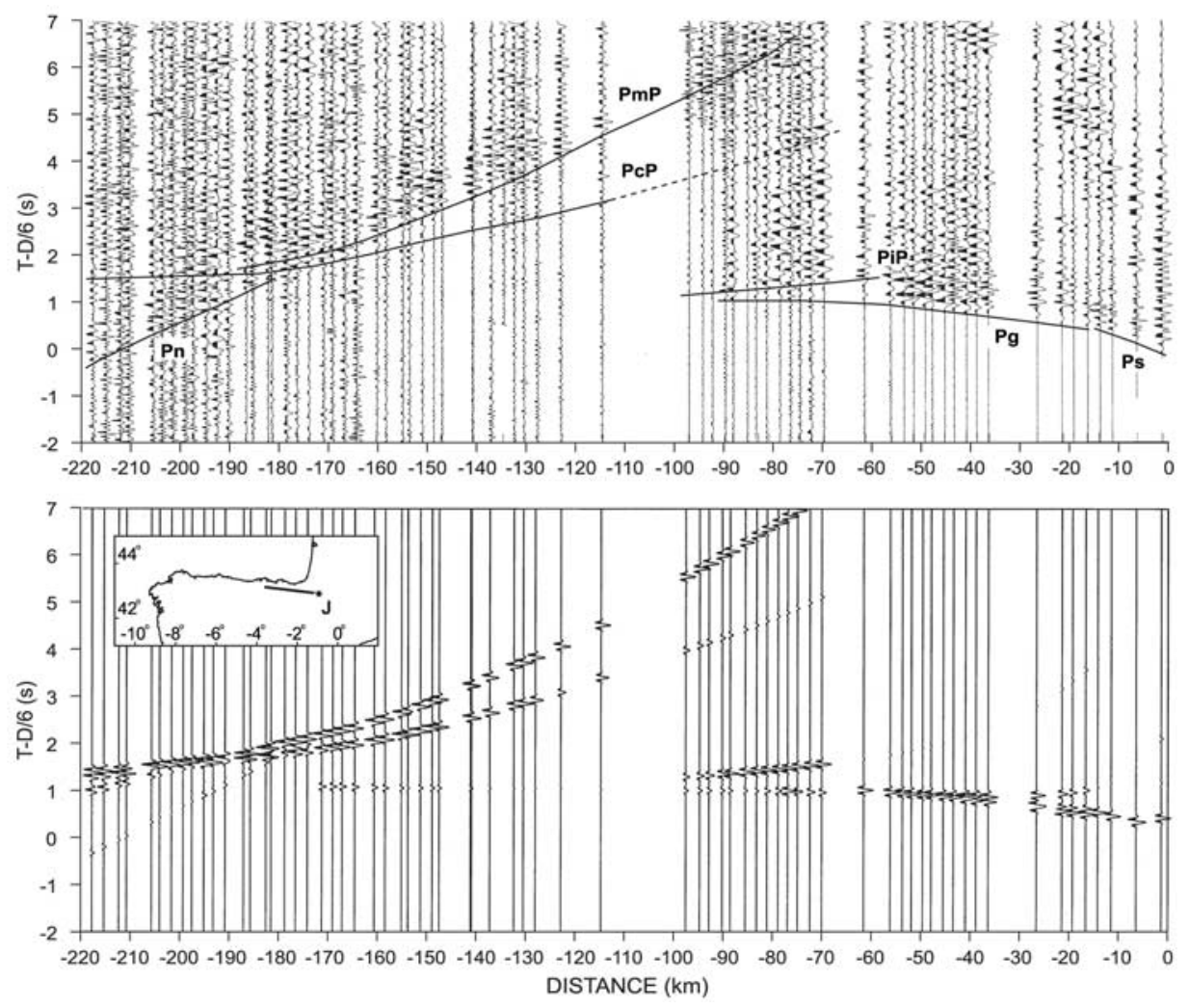

Figure 10. Shot J recorded toward the west along profile 1. (top) Record section. (bottom) Synthetic section from the velocity-depth model of Figure 5.

strong velocity contrast to fit the amplitudes in the synthetic record section. A velocity for the basal layer of $6.75 \mathrm{~km} / \mathrm{s}$ has been used to fit the data. This anomalous body must end abruptly toward the west, as the energy of the $P 1 P$ arrivals rapidly vanishes for distances $>70 \mathrm{~km}$ both in trace-normalized and in true amplitude record sections. The $P c P$ is observed from $\sim 95 \mathrm{~km}$ offsets ( $2.75 \mathrm{~s}$ reduced time) and is a relatively weak phase compared with the reflection at the Moho. This PmP phase is observed from $70 \mathrm{~km}$ onward, $\sim 20 \mathrm{~km}$ closer and $1.5 \mathrm{~s}$ earlier (at a distance of $100 \mathrm{~km}$ ) than in the case of shot B to the east, hence revealing some decrease in the crustal thickening of the area between shot points A and I and constraining the $39-40 \mathrm{~km}$ depth of the Moho estimated from shot A to the east.

[19] Shot I to the east (Figures $3 \mathrm{c}$ and 8 ) shows a long $P S$ arrival up to $40 \mathrm{~km}$ from the shot point, with apparent velocities increasing from 5.25 to $5.65 \mathrm{~km} / \mathrm{s}$. Between 40 and $75 \mathrm{~km}$ a weak $P g$ phase is observed with an apparent velocity of $5.9 \mathrm{~km} / \mathrm{s}$. At the base of this upper crustal layer a strong reflection is found from 40 to $75 \mathrm{~km}$ offsets, again with a sharp end to the east. This reflection has been labeled $P 1 P$ in analogy with shot I to the west. A difference in this case is that after $P 1 P$, another energetic reflection is seen between 55 and $105 \mathrm{~km}$ offsets. Travel times and amplitudes of the latter phase were fitted with an interface located at $16-$ $17 \mathrm{~km}$ depth with materials of velocity $6.60-6.70 \mathrm{~km} / \mathrm{s}$ beneath it. The nature and depth of this reflection are very similar to the one observed in shot $\mathrm{B}$ between $P i P$ and $P c P$, and for this reason it has been labeled $P 2 P$. At offsets between 75 and $160 \mathrm{~km}$ an energetic but rather diffuse arrival can be observed at reduced times of 4.8-2.1 s (at distances $>160 \mathrm{~km}$ the signal-to-noise ratio becomes very low and correlation of seismic phases is not possible). We interpret this energy as the $P c P$ phase, although this assumption is not straightforward. The absence of a later clear energetic arrival could suggest that it corresponds to the PmP phase. However, in the record sections of the horizontal components a later phase is, in fact, observed (Figure 9), which can be more reliably attributed to the $S m S$. Moreover, $P c P$ and $P m P$ are clear phases in the reversed profile from shot $\mathrm{J}$ to the west (Figures 3d and 10), and the arrival times at half distances corroborate our interpretation. The change in the dominant energetic phase between $P c P$ and $P m P$ in shots I and $\mathrm{J}$ required a strong lateral variation of seismic velocities for the lower crust, from $7.35-7.40 \mathrm{~km} / \mathrm{s}$ westward to $6.60-$ $6.80 \mathrm{~km} / \mathrm{s}$ eastward of the Pamplona Fault (Figure 5).

[20] There are also differences in shallow structure at both sides of the Pamplona Fault. Shot J (Figures 3d and 10) shows a very short $P s$ phase observed up to a distance of only $15 \mathrm{~km}$, revealing the drastic decrease in the thickness of the Mesozoic-Tertiary deposits at the eastern side of the Pamplona Fault as compared to the thickness of the deposits in the Basque-Cantabrian Basin. The gradual increase in the apparent velocity of the $P g$ phase denotes the existence of different levels within the upper part of the basement. $P g$ can be correlated from 15 to $90 \mathrm{~km}$ offset with rather strong energy up to $60 \mathrm{~km}$. A reflection at the base of the upper crust (PiP) can be clearly identified from 60 to $100 \mathrm{~km}$ and corresponds to a velocity increase from 6.10 to $6.20-6.25 \mathrm{~km} / \mathrm{s}$. The $P c P$ phase is weak and is not obvious for offsets outside the range 

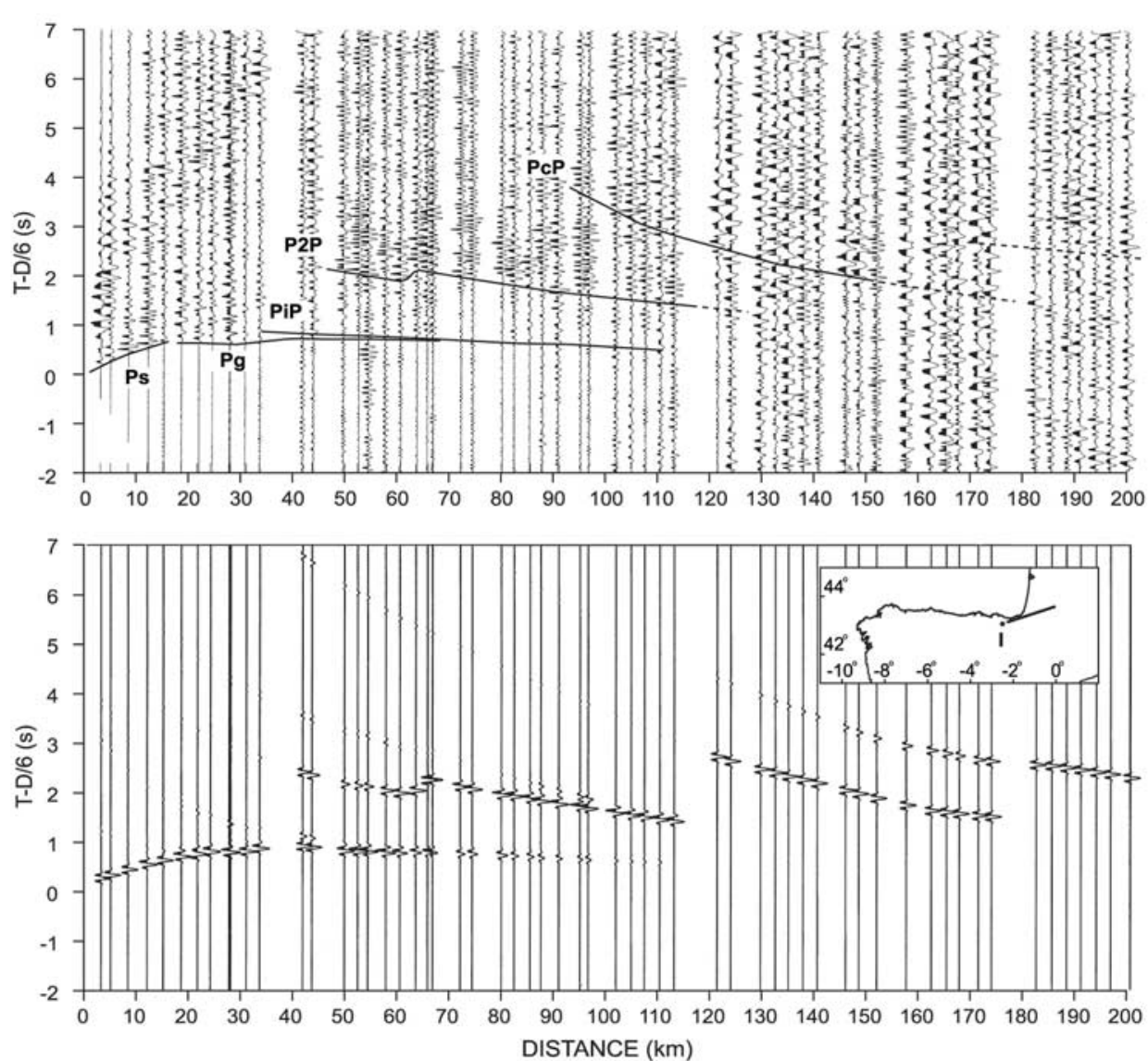

Figure 11. Shot I recorded toward the NE along profile 8. (top) Record section. (bottom) Synthetic section from the velocity-depth model of Figure 13.
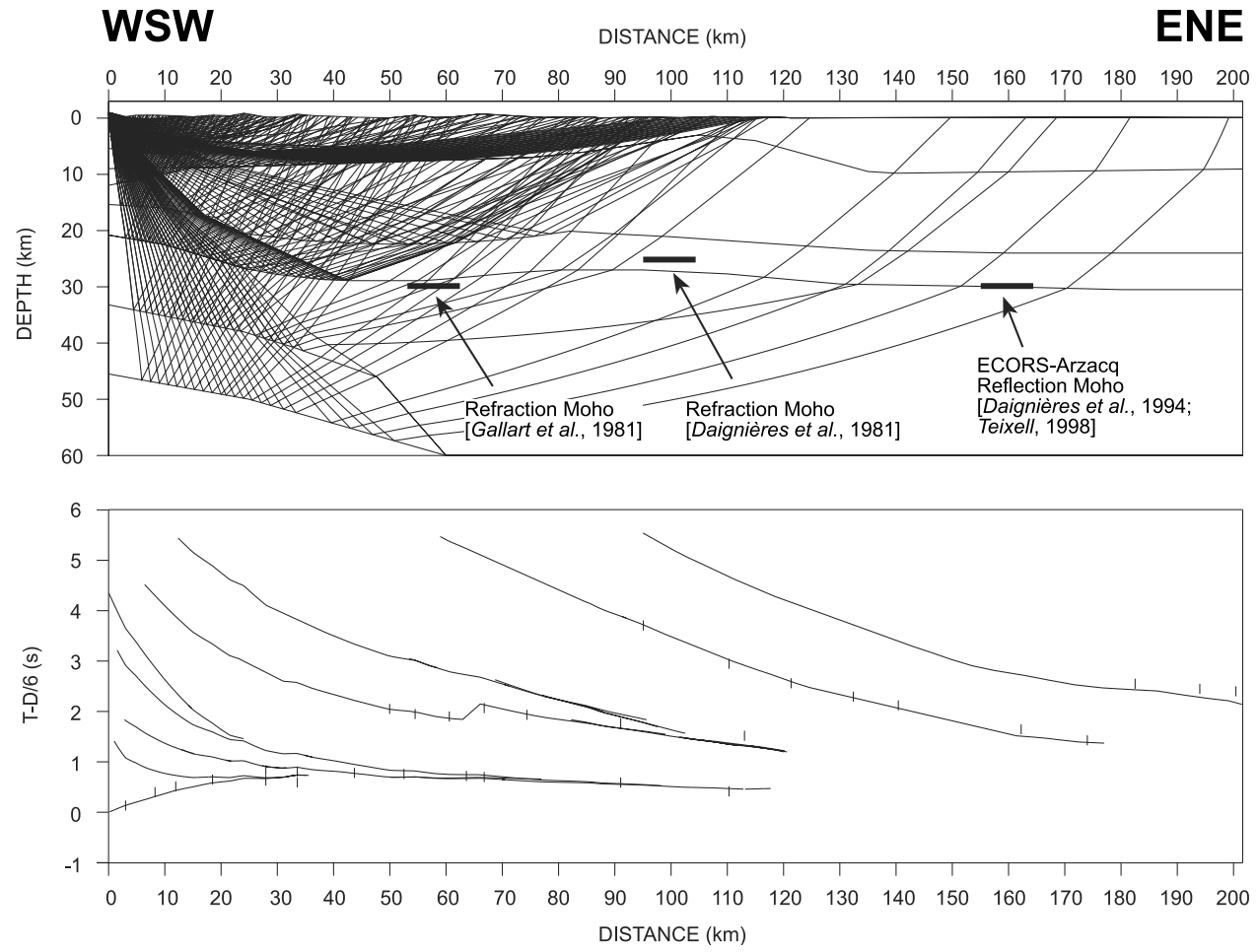

Figure 12. Ray tracing and fitting between observed (short vertical lines) and calculated (solid lines) travel times for shot I recorded toward the NE along profile 8. All the reflected and refracted (diving) rays and arrivals are shown. The velocity-depth model used is illustrated in Figure 13. 


\section{WSW}

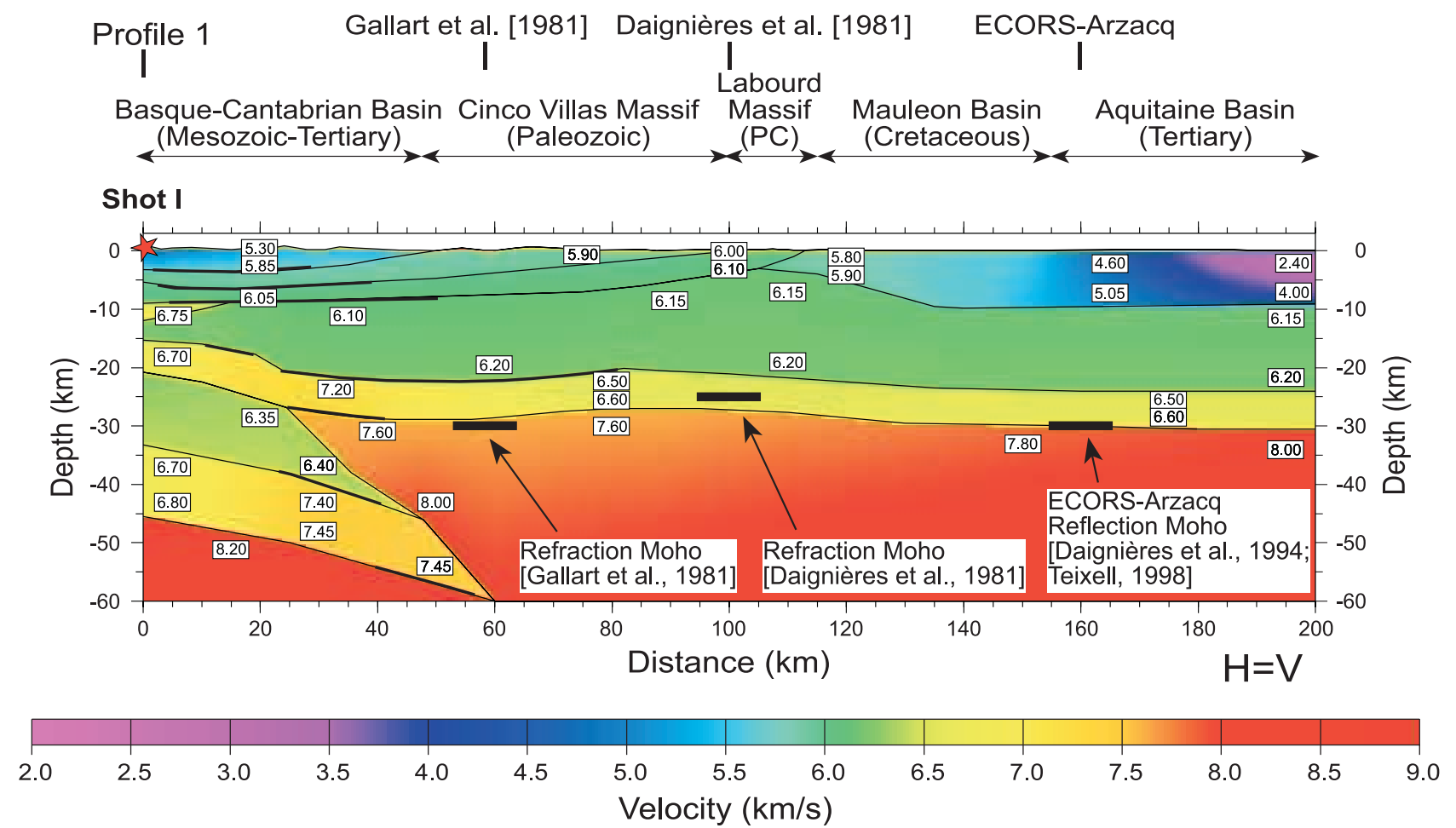

Figure 13. Velocity-depth model obtained for profile 8 . Intersection with profile 1 is indicated, as well as the geological zones crossed. Numbers in white boxes indicate representative velocities. Bold lines indicate layer segments directly sampled by seismic reflections. See Figure 1 for location.

of $115-140 \mathrm{~km} . P m P$ is a strong, dominant phase from 90 ( $5.7 \mathrm{~s}$ reduced time) to $190 \mathrm{~km}$ offsets $(3.5 \mathrm{~s})$. Its steep slope can be fitted by considering the higher velocities for the lower crust west of the Pamplona Fault.

[21] In conclusion, the velocity-depth model obtained along the E-W transect from the Cantabrian Mountains to the west central Pyrenees (Figure 5) reveals the high degree of structural complexity of this area. High-velocity bodies are found at midcrustal depths beneath the Cantabrian Mountains and the eastern Basque-Cantabrian Basin. Several geological and geophysical constraints suggest that these bodies should represent portions of the lower crust of the Cantabrian Margin (European plate) indenting into the Iberian plate. The lateral variation in velocity values can be seen as a reflection of their different degrees of tectonization during the indentation. The discontinuous presence of this wedge along profile 1 can be explained in terms of relative displacements along N-S to NW-SE structures under the N-S compressional regime as will be discussed in section 5 . The areas of greater crustal thickness along this profile coincide with the areas where the indenting wedge was cut except for the Pyrenean domain to the east of the Pamplona Fault, where the European lower crust must be present only a few kilometers to the north of the transect, taking into account the interpretations of the ECORS-Arzacq [Daignières et al., 1994; Teixell, 1998] and ECORS-Pyrenees [ECORS Pyrenees Team, 1988; Muñoz, 1992] seismic reflection profiles.

[22] In contrast with the 30- to 32-km-thick Variscan crust of the western end of profile 1, constrained by Córdoba et al. [1987, 1988] and Fernández-Viejo et al.
[2000], the Pyrenean and Cantabrian thickened crusts, with Moho depths of the order of 46-48 km, can be considered as one continuous feature despite the minor thickening beneath the western Basque-Cantabrian Basin (39-40 km). The maximum depth of this crustal root is even larger $(\sim 55 \mathrm{~km})$ to the north of this transect [Pulgar et al., 1996; Fernández-Viejo et al., 1998], where the indenting wedge is better expressed and developed.

\subsection{Further Evidence of the Imbrication Between European and Iberian Plates: Profile 8}

[23] The aim of the 200-km-long WSW-ENE profile 8 was to map the transition from the Basque-Cantabrian Basin to the North Pyrenean Zone and the Aquitaine Basin and hence to investigate the deep contact between the Iberian and European plates. However, it must be noted that this profile is oriented obliquely to the main Alpine trends of the Pyrenees, which may result in a slightly distorted view of the collision zone.

[24] The interpretation of this profile is conditioned by the recording of only one shot (shot I at the southwestern end). There is, however, some control in the structure at the crossing points with E-W refraction profiles across the Pyrenees [Daignières et al., 1981; Gallart et al., 1981] and with the ECORS-Arzacq reflection profile [Daignières et al., 1994; Teixell, 1998]. Moho depths of 25-30 km and high velocities of $5.80-5.90 \mathrm{~km} / \mathrm{s}$ for the Mesozoic Mauléon Basin are documented by these studies.

[25] The record section from shot I along profile 8 is shown in Figure 11. It shows important differences with 
respect to the segment recorded from the same shot point along profile 1 to the east, although both profiles run at only $25^{\circ}$ from each other. The structure in the southwestern end has been introduced according to the structure obtained
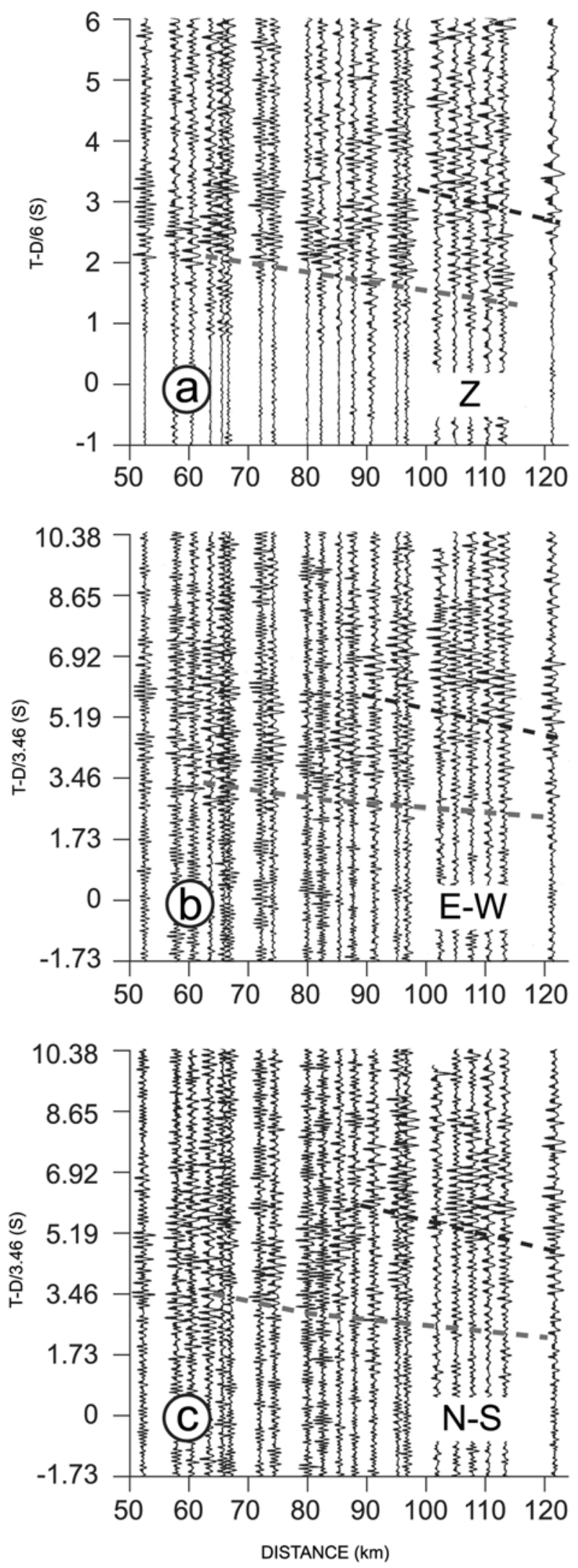

along profile 1. $P s, P g$, and $P i P$ phases have been fitted with a sedimentary cover of $4-5 \mathrm{~km}$ thickness, with velocities ranging from $4.80-5.40 \mathrm{~km} / \mathrm{s}$ at the surface to $5.60-5.85 \mathrm{~km} / \mathrm{s}$ at the bottom, with two levels within the basement with velocities ranging between 5.85 and $6.10 \mathrm{~km} / \mathrm{s}$ and a middle crust beginning at $9-10 \mathrm{~km}$ depth with velocities of $6.10-6.20 \mathrm{~km} / \mathrm{s}$ (Figures 12 and 13). The high-velocity body shown in the southwestern end of the model at this level corresponds to the uppermost anomalous body visible along profile 1 . There is no evidence for an energetic reflection at this shallow depth across profile 8 , and for this reason such a body must end abruptly, in agreement with the image obtained from shot point I to the east along profile 1 .

[26] The most outstanding feature of the record section of profile 8 is the presence of a strong arrival with dominant energy between 50 and $125 \mathrm{~km}$ offsets at reduced times between 2 and $1.3 \mathrm{~s}$, with a jump of $\sim 0.25 \mathrm{~s}$ at $60-65 \mathrm{~km}$ (labeled $P 2 P$ in Figure 11). This energy corresponds to a reflection along an interface located at $16-22 \mathrm{~km}$ depth. It is not plausible, then, to assign this reflection to the European Moho since it would correspond to a very thin crust not supported by the general geotectonic structure of the area. The depth of the interface and the interpreted velocities of $6.7-7.2 \mathrm{~km} / \mathrm{s}$ beneath that level strongly suggest that it corresponds to the top of the lower crust of the European domain (Figure 12). Following its slope beneath shot point I, it connects with the deeper anomalous body detected along profile 1 . Therefore this $P 2 P$ reflection gives further support to the interpretation of the anomalous bodies along profile 1 as being the lower crustal wedge of the EuropeanCantabrian Margin domain indenting into the Iberian crust.

[27] According to the structure beneath shot point I in profile 1, later reflections from the top or the bottom of the Iberian lower crust should be present in the data, although they are not clear in the record section of Figure 11. Therefore a detailed analysis of the data from the two horizontal components has been made. Figure 14 shows the record sections from the three components for the most interesting segment of the profile, between 50 and $120 \mathrm{~km}$. The energetic phase of the vertical record section $(P 2 P)$ is also visible in the horizontal components (gray dashed line), although a later arrival can be correlated more clearly (black dashed line). This later phase can also be identified in the vertical record section $\sim 2 \mathrm{~s}$ later than the most energetic one and with arrival times similar to those found for the Iberian $P_{C} P$ from the same shot point to the east along profile 1 (Figure 8). This observation, and the fact that the energy of the $P c P$ dominates over the $P m P$ along profile 1, suggests that it corresponds to the reflection at the top of the Iberian lower crust in a zone where the lower crustal rocks also reach high-velocity values. A later reflection from the

Figure 14. (opposite) (a) Blowup of the $P$ section (vertical component, $V r=6 \mathrm{~km} / \mathrm{s}$ ) of shot I recorded toward the NE along profile 8, showing the arrivals of the European $P c P$ (gray dashed line) and the Iberian $P C P$ (black dashed line). (b and c) Corresponding $S$ sections (E-W and N-S components, respectively), with $V r=3.46 \mathrm{~km} / \mathrm{s}$ and with a $\sqrt{3}$ factor at the timescale relative to the $P$ section, showing the equivalent $S$ phases. See text for details. 

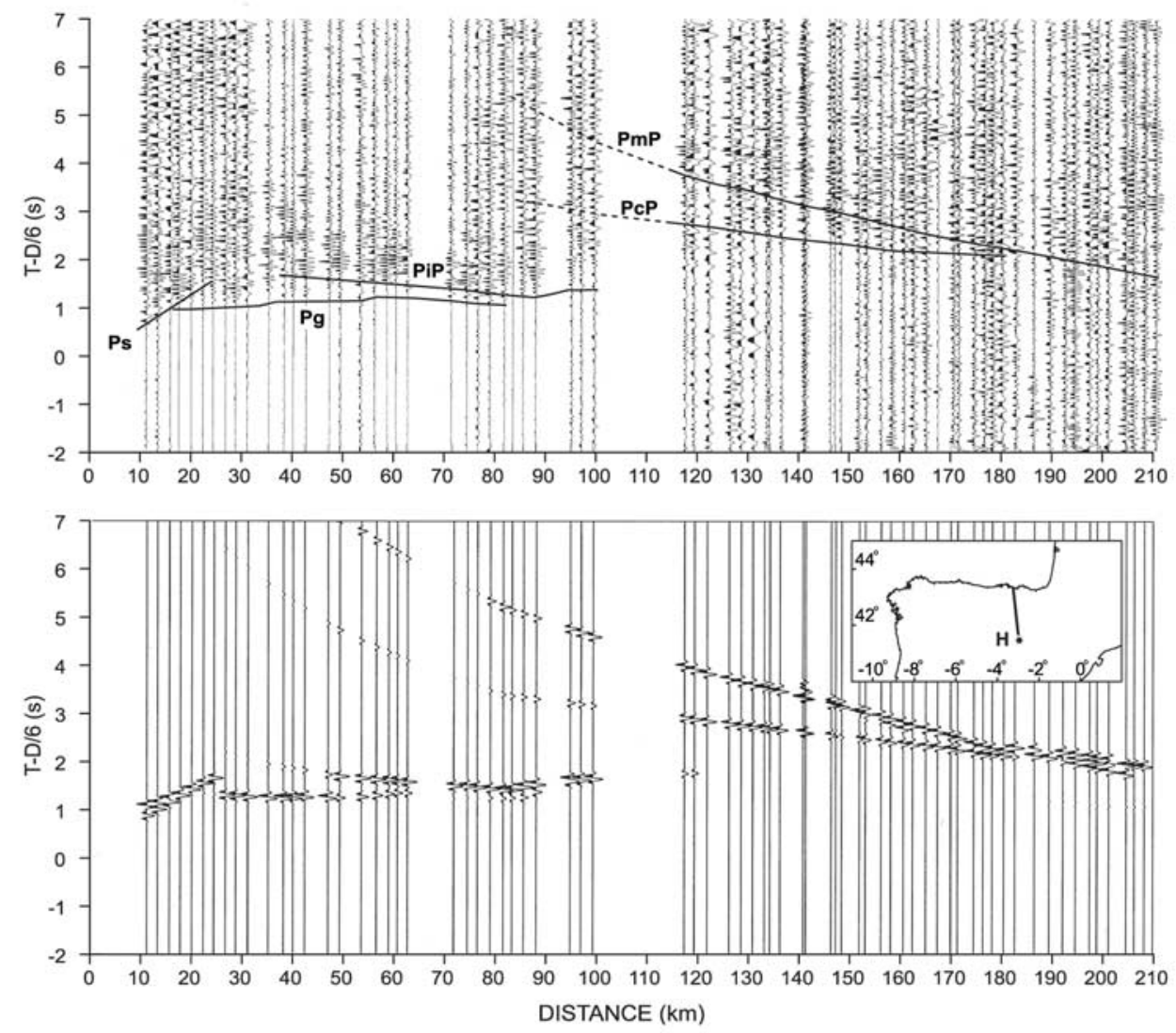

Figure 15. Shot $\mathrm{H}$ recorded northward along profile 6. (top) Record section. (bottom) Synthetic section from the velocity-depth model of Figure 18.

bottom of the northeast dipping Iberian lower crust produces a low-energy arrival, which could be correlated to some energy observed in Figure 11 at distances of 180-200 km and reduced times of $2.5-3 \mathrm{~s}$ (dashed line).

[28] The structural scheme shown in Figure 13 resembles the gravity transect modeled by Casas et al. [1997] in the western Pyrenees, but with a "stretched" perspective due to the obliquity of profile 8 with respect to the Alpine trends. It is also very similar to the crustal interwedging observed to the east in the central Pyrenees [ECORS Pyrenees Team, 1988; Choukroune and ECORS Team, 1989; Muñoz, 1992] and to the west in the Cantabrian Mountains [Pulgar et al., 1996, 1997].

\subsection{North-South Transect From the Basque-Cantabrian Basin to the Iberian Chain}

[29] The transition from the Basque-Cantabrian Basin to the Iberian Chain in a N-S direction perpendicular to the Alpine trends is investigated by profile 6 . This profile has a length of $260 \mathrm{~km}$ and has been recorded by two shots, $\mathrm{H}$ and $\mathrm{K}$, located at 49 and $219 \mathrm{~km}$ from its southern end, respectively. Profile 1 is crossed $16 \mathrm{~km}$ to the north of shot point $\mathrm{K}$.

[30] Data for shot $\mathrm{H}$ are presented in Figures 15 (record section and synthetic seismograms) and 16a (fitting of arrival times). Ps waves travel across the Tertiary succession of the Almazán Basin with an apparent velocity of $\sim 4.5 \mathrm{~km} / \mathrm{s}$. The short crossover distance and arrival times of the $P g$ phase (15 km and $1 \mathrm{~s}$, respectively) reveal a thin sedimentary cover. The $P g$ phase shows a step-like pattern, and this feature has been modeled by layering in the upper crust. The apparent velocity increases slightly up to $6 \mathrm{~km} / \mathrm{s}$ at distances between 60 and $85 \mathrm{~km}$ from the shot point, which corresponds to the outcrop of Paleozoic rocks of $\mathrm{La}$ Demanda massif in the frontal part of the Iberian Chain (Figure 1). PiP can be observed at distances from 40 to $100 \mathrm{~km}$, with some delay after $85 \mathrm{~km}$ owing to the presence of the thick Tertiary succession of the Ebro Basin. $P C P$ is a rather diffuse phase that is not obvious for distances outside the range of $125-180 \mathrm{~km}$, where it is observed at reduced times between 2.5 and $2 \mathrm{~s}$. This is a relatively late phase, revealing a midcrustal thickening below the front of the Iberian Chain. The PmP phase can be correlated from $115 \mathrm{~km}$ to the end of the profile. The delay of travel times relative to $P c P$ indicates a lower crustal thickness of $\sim 10 \mathrm{~km}$.

[31] Shot K (Figures 16b and 17), located in the BasqueCantabrian Basin, shows marked differences in comparison to shot H. Ps can be identified as the first arrival up to a distance of $30 \mathrm{~km}$, revealing the thick Mesozoic succession of the Basque-Cantabrian Basin. Average apparent velocity is $4.75 \mathrm{~km} / \mathrm{s}$. $P g$ arrivals are very weak in this section, in contrast to the $P i P$ reflection at the base of the upper crust, well expressed from 30 to $80 \mathrm{~km}$. This arrival has been modeled with a north dipping interface at 8-12 km depth, beneath which velocities reach values of $6.15-6.20 \mathrm{~km} / \mathrm{s}$, which is typical for the middle crust. $P c P$ is very clear and can be correlated from $90 \mathrm{~km}$ (at $3.4 \mathrm{~s}$ reduced time) to the 


\section{S \\ DISTANCE $(\mathrm{km})$ \\ $\mathbf{N}$}

(a)
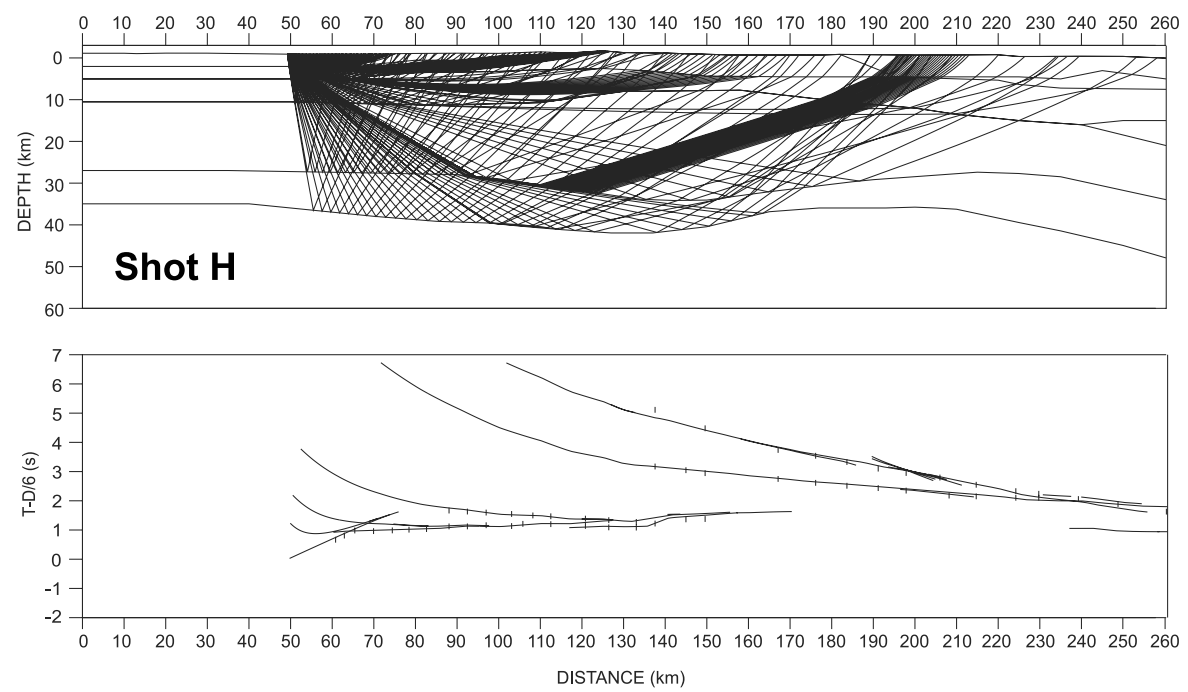

DISTANCE $(\mathrm{km})$

(b)
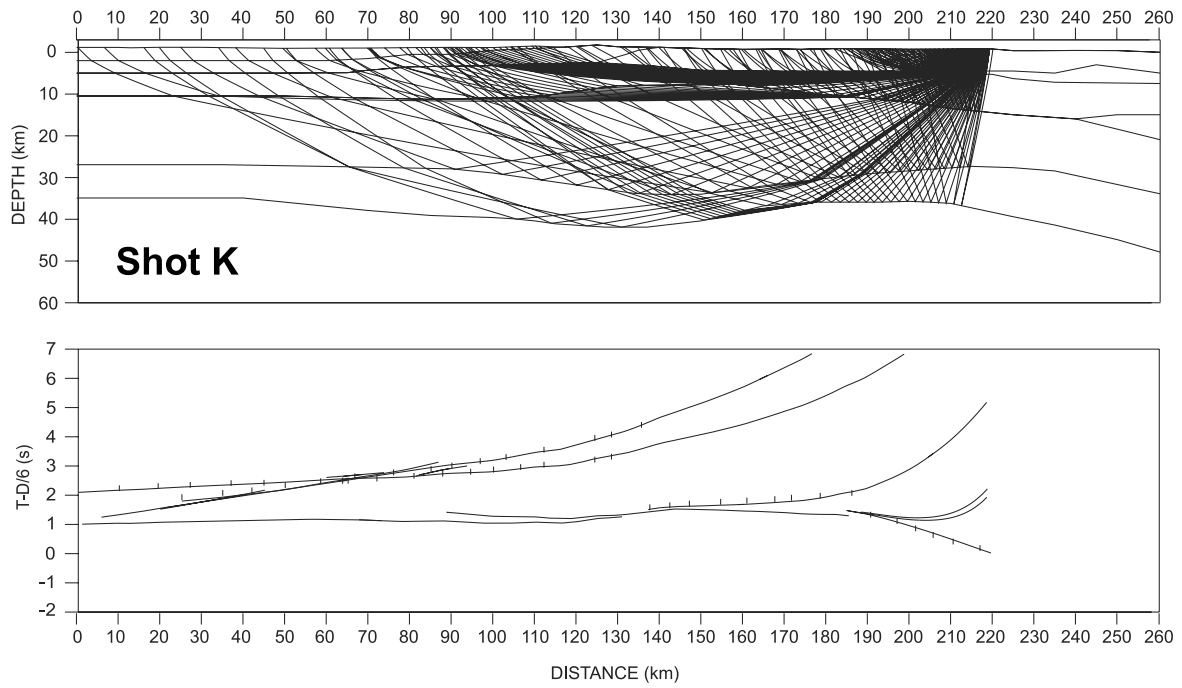

Figure 16. Ray tracing and fitting between observed (short vertical lines) and calculated (solid lines) travel times for (a) shot $\mathrm{H}$ and (b) shot $\mathrm{K}$ along profile 6 . All the reflected and refracted (diving) rays and arrivals are shown. The velocity-depth model used is illustrated in Figure 18.

end of the profile $(2.2 \mathrm{~s})$. The important delay between $P i P$ and $P c P$ arrivals and the very gentle slope of $P c P$ delineate a thickened middle crust with a south dipping base toward the front of the Iberian Chain. The strong $P c P$ arrivals between 90 and $110 \mathrm{~km}$ indicate a clear velocity contrast between the middle and lower crust in the northern part of the profile. Velocities of $6.90-6.95 \mathrm{~km} / \mathrm{s}$ were necessary to fit the amplitudes in the synthetic section (Figure 17). The $P m P$ reflection arrives close to $P c P$ (crossing it at around $160-170 \mathrm{~km}$ offsets), revealing a thinning of the lower crust beneath the Ebro Basin to $\sim 5-7 \mathrm{~km}$.

[32] Figure 18 shows the velocity-depth model for profile 6 . The structure to the north of shot point $\mathrm{K}$ is fixed only from the information at the crossing point with profile 1. The most outstanding feature of this model is the thickening of the middle crust beneath the frontal thrust of the Iberian Chain. This layer can reach $>25 \mathrm{~km}$ with velocity values of
$6.15-6.20 \mathrm{~km} / \mathrm{s}$. The lower crust shows a progressive increase in velocity, from $6.60-6.75 \mathrm{~km} / \mathrm{s}$ in the south to $6.95-7.00 \mathrm{~km} / \mathrm{s}$ beneath the Ebro Basin, decreasing slightly again toward the north to $6.75-6.85 \mathrm{~km} / \mathrm{s}$. The thickness of this layer is rather constant (from 8 to $10 \mathrm{~km}$ ) except for the area beneath the Ebro Basin, where the inferred thickness is $\sim 5-7 \mathrm{~km}$. The overall structure of this profile, with Moho depths of 40-42 km beneath the mountain front of the Iberian Chain and a relatively thin lower crust, is very similar to the one obtained by Salas and Casas [1993] using a gravity model across the central part of this mountain range, a few tens of kilometers to the southeast of profile 7 .

[33] Profile 7 was sampled from two shots in location $\mathrm{J}$ at its northeastern end (Figure 1). The interpretation is again conditioned by the absence of a reversed profile, and constraints are limited to the crossing points with profiles 1 and 6 at both ends. The shallowing of the lower crust and Moho 

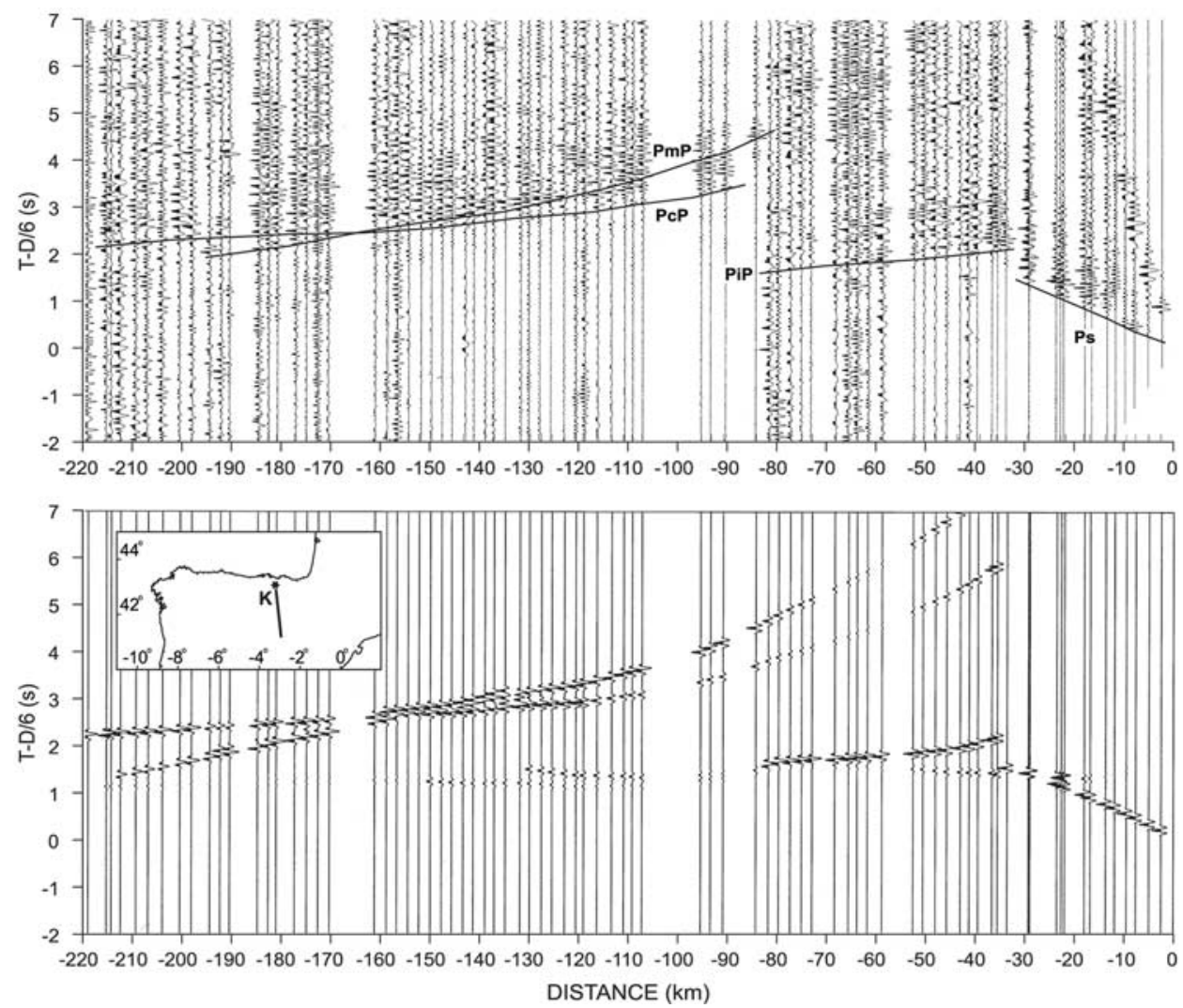

Figure 17. Shot $\mathrm{K}$ recorded toward the south along profile 6. (top) Record section. (bottom) Synthetic section from the velocity-depth model of Figure 18.

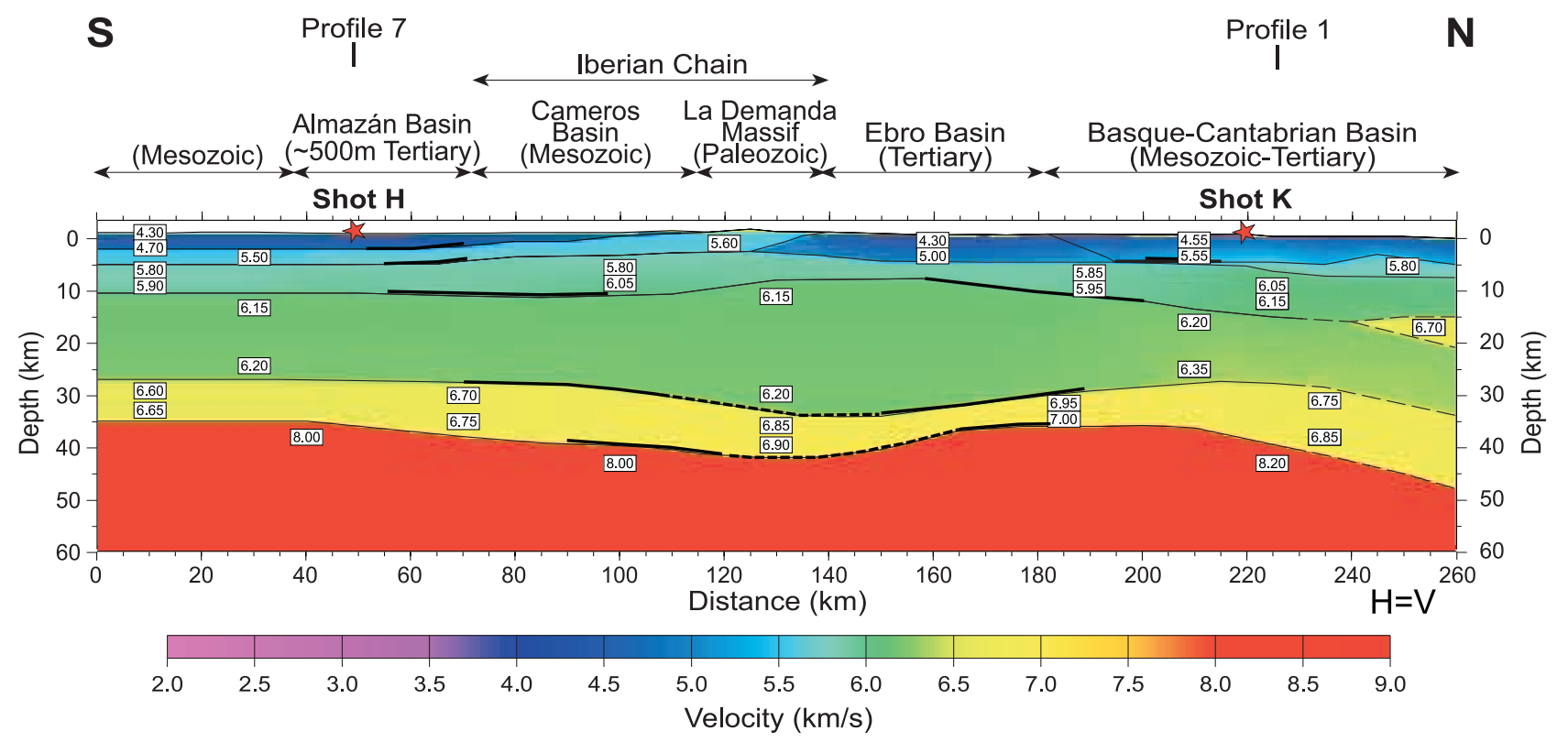

Figure 18. Velocity-depth model obtained for profile 6. Intersections with profiles 1 and 7 are indicated, as well as the geological zones crossed. Numbers in white boxes indicate representative velocities $\left(\mathrm{km} \mathrm{s}^{-1}\right)$. Bold lines indicate layer segments directly sampled by seismic reflections. The deep structure to the north of shot point $\mathrm{K}$ (dashed lines) is not covered by rays and is inferred only from the modeling of profiles 1 and 8. See Figure 1 for location. 
(a)
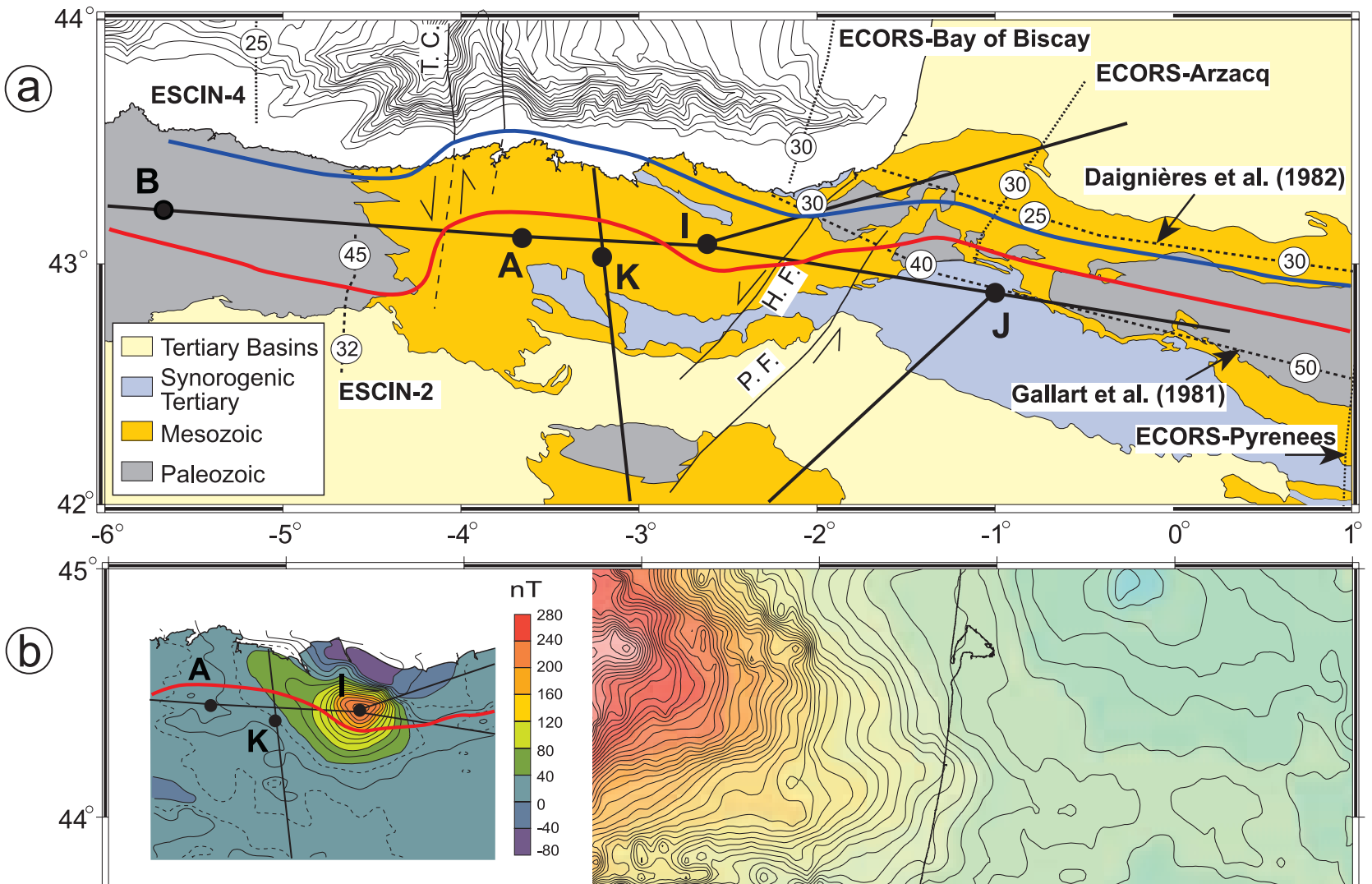

(b)

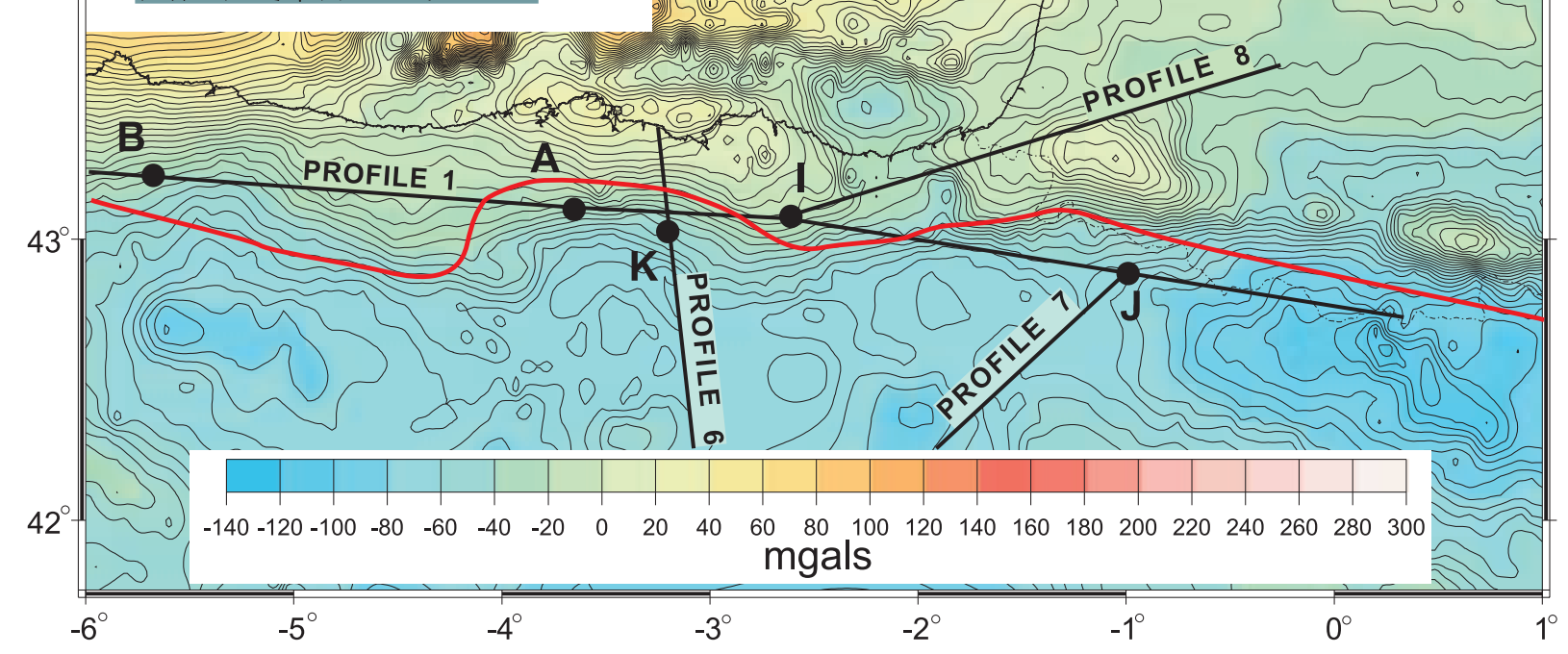

Figure 19. (a) Simplified geological map of the Basque-Cantabrian Basin and adjacent areas, showing the location of the seismic profiles used in the delimitation of the northernmost prolongation of the Iberian lower crust (blue line) and the southernmost position of the lower crust from the European domain (red line). Numbers in white circles represent values of crustal thickness $(\mathrm{km})$ documented along previous seismic lines. HF, Hendaya Fault; PF, Pamplona Fault; TC, Torrelavega Canyon. (b) Bouguer anomaly map obtained from our own data and data provided by the Bureau Gravimétrique International and the GeoFrance3D Project [Grandjean et al., 1998] (reduction density of $2670 \mathrm{~kg} / \mathrm{m}^{3}$ and variable terrain corrections). Note that the trace of the southernmost position of the European-Cantabrian Margin lower crust follows approximately the southern gradient of the highest anomalies (see text for details). Inset is an aeromagnetic map of the area surrounding shot points A, I, and K. The anomaly over shot point I is the highest of the Spanish mainland [Ardizone et al., 1989]. 


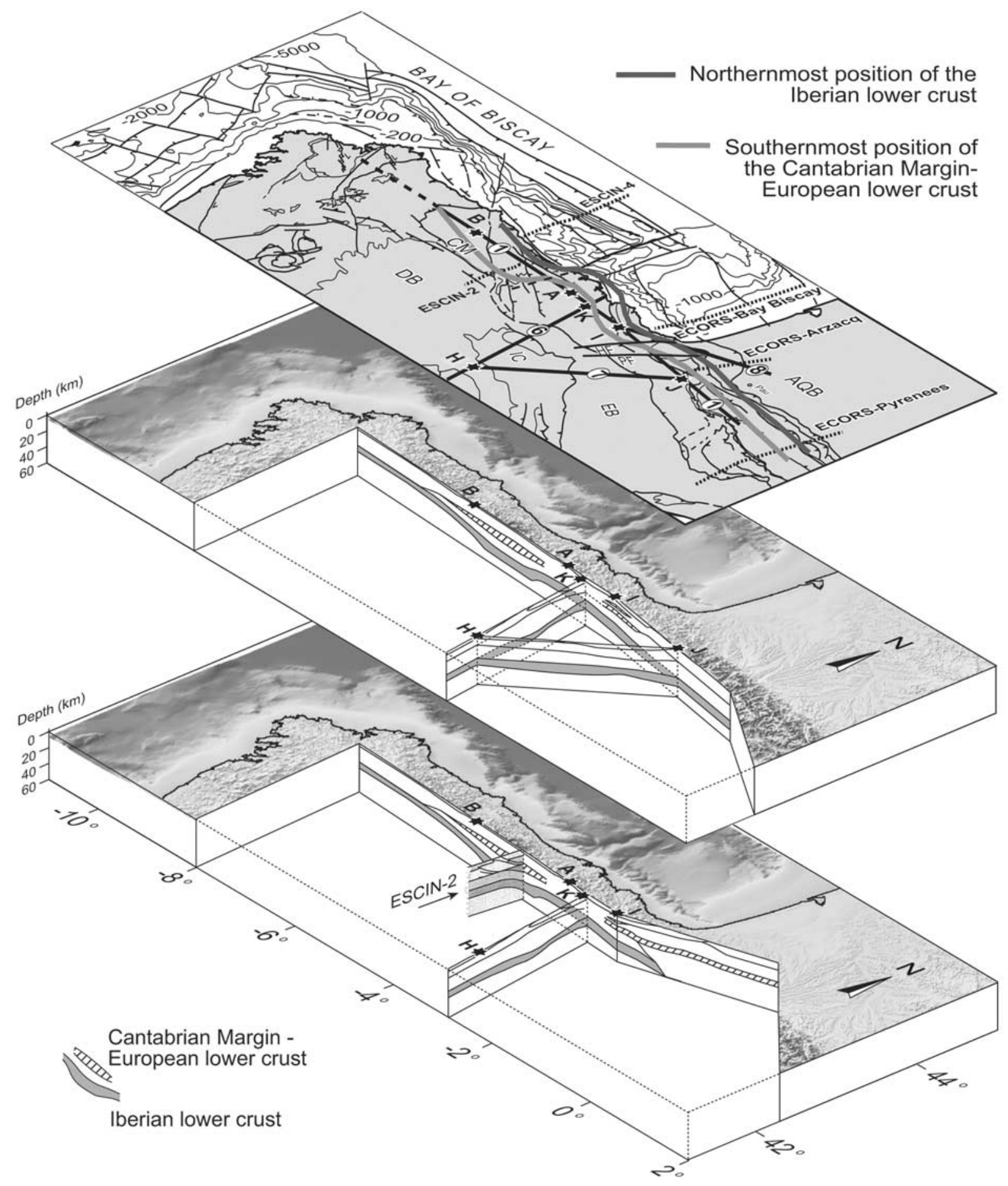

Figure 20. Three-dimensional reconstruction of the crustal structure in North Iberia derived from the profiles explained in the text. (top) Simplification of the tectonic map of Figure 1 showing the location of the seismic profiles and the inferred trace of the northernmost position of the Iberian lower crust and the southernmost position of the Cantabrian Margin-European lower crust. AB, Almazán Basin; AQB, Aquitaine Basin; CM, Cantabrian Mountains; DB, Duero Basin; EB, Ebro Basin; HF, Hendaya Fault; IC, Iberian Chain; PF, Pamplona Fault. (middle) Three-dimensional reconstruction showing the disposition of the Iberian lower crust (solid) and the Cantabrian Margin-European lower crust (striped) along profiles 1,6 , and 7. The seismic data and velocity-depth model for profile 7 are not displayed in this paper. (bottom) Three-dimensional reconstruction along profiles 6, 8, and 1 from the western end to shot point I. The location of the ESCIN-2 profile is also shown. 
from shot point $\mathrm{J}$ to the Ebro Basin prevent the rays from imaging the deep structure of the Iberian Chain, and only the structure beneath the Ebro Basin can be determined. The lower crust is $\sim 10 \mathrm{~km}$ thick in the SW and thins to 7-8 $\mathrm{km}$ beneath the basin where Moho depths are found to be $36-38 \mathrm{~km}$, deepening toward the Iberian Chain and the Pyrenees.

\section{Discussion and Tectonic Implications}

[34] The complex crustal structure of North Iberia, a consequence of the Alpine collision between the Iberian and European plates, is evidenced in the interpretation of the new seismic data. The most conspicuous tectonic feature inferred from our modeling is the presence of a thinner and stronger European crust protruding into the thicker Iberian crust, promoting its northward underthrusting and the generation of the doubly-vergent orogen at upper crustal to midcrustal levels. The seismic results show that this is a widespread feature observed from the Pyrenees to the Cantabrian Mountains across the Basque-Cantabrian Basin. Moho depths are of the order of 46-48 km along the E-W transect delineated by profile 1 except for the western Basque-Cantabrian Basin, where the crust-mantle boundary is located at $39-40 \mathrm{~km}$ depth. This local difference can be explained by the higher degree of crustal extension focused in this zone and by the absence of the lower crustal wedge of the European domain in this sector of the profile, although it should be present farther north. In the thickened crust of the eastern part of the transect the indenting wedge is also absent, but in this area the crust was originally thicker, and the wedge must be present only a few kilometers to the north as has been observed in the ECORS-Arzacq and ECORSPyrenees profiles. This discontinuous presence of the European lower crust along profile 1 can be explained by relative left-lateral displacements, under the N-S to NNW-SSE compressional regime, along NE-SW oriented structures like the Pamplona and Hendaya Faults, as well as along an inferred N-S structure at the meridian of the Torrelavega Canyon (Figure 19a). The onshore prolongation of this deep structure is not obvious, but a late Variscan or early Mesozoic structure may be present beneath the Mesozoic cover of this area, favoring a left-lateral displacement of the basement during the Alpine collision.

[35] Compiling present results and those from previous seismic surveys allows us to trace the surface projection of the southernmost position of the European-Cantabrian Margin lower crust and the northernmost position of the Iberian lower crust (Figures 19a and 20). By plotting these lines over a Bouguer anomaly map, it can be observed that the southern end of the European lower crust approximately follows the highest southern gradient of a series of positive gravity anomalies distributed from the Pyrenees to the Cantabrian Mountains (Figure 19b). The nature of these positive anomalies is different from east to west: In the western Pyrenees and in the Basque-Cantabrian Basin, anomalies are of very high amplitude owing to the presence of dense bodies at depths from 8 to $13 \mathrm{~km}$ [e.g., Grandjean, 1994; Casas et al., 1997]. The anomaly in the western Pyrenees over the Mauléon Basin coincides with an area of high seismic velocity $(6.7-6.8 \mathrm{~km} / \mathrm{s})$, which has been interpreted by Daignières et al. [1981] as being due to the presence of a body between 9 and $20 \mathrm{~km}$ depth with a density contrast of $0.25 \mathrm{~g} / \mathrm{cm}^{3}$ compared to the main crustal density. Casas et al. [1997] explain the anomaly with a body of mantle density located above the lower crust of the European plate at depths between $\sim 9$ and $13 \mathrm{~km}$. This body could have ascended during the Mesozoic extension or in a transtensional regime related to the inferred left-lateral motion between the Iberian and European plates, and it could be placed at these shallow depths by a north directed thrust during the Alpine compression.

[36] The anomalous body beneath the Mauléon Basin is located at the same depth $(9-10 \mathrm{~km})$, has the same seismic velocity $(6.70-6.80 \mathrm{~km} / \mathrm{s})$, and creates a gravity anomaly of similar amplitude and wavelength as the shallowest one found beneath shot point I along profile 1. Casas et al. [1997] interpret the absence of significant positive gravity anomalies in the eastern Pyrenees as being due to the fact that the Mesozoic extension was greater in the west; in fact, south of the Parentis Basin, this extension was mainly focused on the Basque-Cantabrian Basin, where even volcanic events took place in Late Cretaceous times. All these observations suggest that the anomalous body of velocity $6.75 \mathrm{~km} / \mathrm{s}$ located at $9 \mathrm{~km}$ depth beneath shot point I must have an origin and evolution similar to that present under the Mauléon Basin. The connection between both gravity anomalies in the map follows the same bend observed in the trace of the surface Alpine structures (Figure 19a) and can be explained by relative left-lateral movements along the NE-SW Pamplona and Hendaya fault systems under the $\mathrm{N}-\mathrm{S}$ to NNW-SSE compression.

[37] Other evidence for the lower crustal/mantelic origin of the uppermost anomalous body beneath shot point I is that in this area the highest aeromagnetic anomaly of the whole Spanish mainland [Ardizone et al., 1989] is observed (Figure 19b, inset), indicating the presence of mafic or ultramafic rocks at shallow depths. As for the case of the gravity high, the southeast termination of this anomaly coincides approximately with the trace of the Hendaya Fault.

[38] However, it must be noted that the single seismic refraction modeling presented in this paper is insufficient to assess a lower crustal mantelic or mixed composition for the shallowest anomalous body beneath shot point I. The velocity of $6.75 \mathrm{~km} / \mathrm{s}$ used in the final model suggests a lower crustal composition, but this can be considered as the minimum value that is necessary to fit the observed amplitudes of the reflections produced on its top. Slightly higher velocities up to $\sim 6.90 \mathrm{~km} / \mathrm{s}$ can also fit the observations, and even higher values may be present in the lower part of the body. In order to gain insight on its nature it is therefore necessary to combine these seismic results with other geophysical investigations.

[39] Moving from shot point I to the west, gravimetric, magnetic, and structural trends run to the NW, and hence the shallow anomalous body and the lower crust of the European domain beneath it should have the same orientation, passing to the north of profile 1 . However, the inferred deep structure related to the Torrelavega Canyon should facilitate the lower crust of the western block to protrude a little bit more to the south, being cut again by profile 1 and by the ESCIN-2 reflection profile beneath the Cantabrian Mountains. In this sector the shallowest anomalous bodies are not identified in the seismic sections, and consistently, there are 
no gravity anomalies of high amplitude nor relevant aeromagnetic anomalies. Only a positive gravity gradient toward the coast is observed, explained by the presence of the shallower Moho and the indented lower crust of the European-Cantabrian Margin plate, whose positive effect dominates the negative effect of the crustal root [Pedreira, 1998; Gallastegui, 2000]. The indentation and thickening of the crust finally end $\sim 60-70 \mathrm{~km}$ to the west of shot point B, where a typical Variscan crust $30-32 \mathrm{~km}$ thick is found [Córdoba et al., 1987, 1988; Fernández-Viejo et al., 2000].

\section{Conclusions}

[40] The seismic refraction/wide-angle reflection experiment presented in this paper fills a gap of observations between the Pyrenees and the Cantabrian Mountains and provides the basis for a more complete understanding of the deep structure and tectonic evolution of North Iberia. A continuous crustal root is observed along the strike of the Pyrenean-Cantabrian range, with Moho depths reaching 46-48 km except for a local rise beneath the western Basque-Cantabrian Basin to $\sim 40 \mathrm{~km}$ depth. High-velocity bodies $(6.40-6.70 \mathrm{~km} / \mathrm{s})$ are found at $13-16 \mathrm{~km}$ depth and interpreted as portions of the European-Cantabrian Margin lower crust indenting the Iberian crust and forcing its northward underthrusting. The discontinuous presence of such bodies along the E-W profile is explained in terms of left-lateral movements along vertical, N-S to NE-SW oriented structures.

[41] A shallower high-velocity $(6.75 \mathrm{~km} / \mathrm{s})$ body found at $\sim 9 \mathrm{~km}$ depth in the eastern Basque-Cantabrian Basin is interpreted as a retrovergent slice of the EuropeanCantabrian Margin lower crust, probably also incorporating some upper mantle material. This body is likely to be responsible for the strong positive gravity anomaly observed in that area and for the highest aeromagnetic anomaly of the Iberian Peninsula.

[42] To the south of the Pyrenean-Cantabrian range, the Alpine compression promoted the uplift and thickening of the Iberian Chain. This thickening is mainly focused on the middle crust, and Moho depths reach $40-42 \mathrm{~km}$ beneath the northern mountain front.

[43] Acknowledgments. This research was funded by Spanish CICYT projects AMB95-0922 and AMB98-1012. We thank many colleagues from the Universidad de Oviedo, Universidad Complutense de Madrid, Institut de Cièncias de la Terra "Jaume Almera" (CSIC, Barcelona), Instituto Geográfico Nacional (Madrid), Instituto de Ciências da Terra e do Espaço (Lisbon), ETH (Zurich), and IRIS-PASSCAL (especially Mark Álvarez) for their help with the field experiment. We gratefully acknowledge the Bureau Gravimétrique International (BGI) and Gilles Grandjean and Nicole Debeglia (GeoFrance3D project) for the supply of gravity data.

\section{References}

Albarède, F., and A. Michard-Vitrac, Datation du métamorphisme des terrains secondaires des Pyrénées par les méthodes ${ }^{39} \mathrm{Ar}-{ }^{40} \mathrm{Ar}$ et ${ }^{87} \mathrm{Rb}^{87} \mathrm{Sr}$ : Ses relations avec les péridotites associées, Bull. Soc. Geol. Fr., 7, 681-687, 1978 .

Alonso, J. L., J. A. Pulgar, J. C. García-Ramos, and P. Barba, Tertiary basins and Alpine tectonics in the Cantabrian Mountains (NW Spain), in Tertiary Basins of Spain: The Stratigraphic Record of Crustal Kinematics, edited by P. F. Friend and C. J. Dabrio, pp. 214-227, Cambridge Univ. Press, New York, 1996.

Álvarez-Marrón, J., E. Rubio, and M. Torné, Subduction-related structures in the north Iberian Margin, J. Geophys. Res., 102(B10), 22,497-22,511, 1997.
Ardizone, J., J. Mezcua, and I. Socías, Mapa aeromagnético de españa peninsular, Maps 17.344-1989-17.346-1989, Inst. Geogr. Nac., Madrid, 1989.

Casas, A., P. Kearey, L. Rivero, and C. R. Adam, Gravity anomaly map of the Pyrenean region and a comparison of the deep geological structure of the western and eastern Pyrenees, Earth Planet. Sci. Lett., 150, 65-78, 1997.

Choukroune, P., and Etude Continentale et Océanique par Reflexion et Refraction Sismique (ECORS) Team, The ECORS Pyrenean deep seismic profiles reflection data and the overall structure of an orogenic belt, Tectonics, 8, 23-39, 1989.

Córdoba, D., E. Banda, and J. Ansorge, The Hercynian crust in northwestern Spain: A seismic survey, Tectonophysics, 132, 321-333, 1987.

Córdoba, D., E. Banda, and J. Ansorge, $P$-wave velocity-depth distribution in the Hercynian crust of northwestern Spain, Phys. Earth Planet. Inter, 51, 235-248, 1988 .

Daignières, M., J. Gallart, and E. Banda, Lateral variation of the crust in the North Pyrenean Zone, Ann. Geophys., 37(3), 435-456, 1981.

Daignières, M., M. Séguret, M. Specht, and the Etude Continentale et Océanique par Reflexion et Refraction Sismique Team, The Arzacqwestern Pyrenees ECORS deep seismic profile, in Hydrocarbon and Petroleum Geology of France, edited by A. Mascle, pp. 199-208, Springer-Verlag, New York, 1994.

Etude Continentale et Océanique par Reflexion et Refraction Sismique (ECORS) Pyrenees Team, The ECORS deep reflection seismic survey across the Pyrenees, Nature, 331, 508-511, 1988.

Fernández-Viejo, G., J. Gallart, J. A. Pulgar, J. Gallastegui, J. J. Dañobeitia, and D. Córdoba, Crustal transition between continental and oceanic domains along the north Iberian Margin from wide-angle seismic and gravity data, Geophys. Res. Lett., 25(23), 4249-4252, 1998.

Fernández-Viejo, G., J. Gallart, J. A. Pulgar, D. Córdoba, and J. J. Dañobeitia, Seismic signature of Variscan and Alpine tectonics in NW Iberia: Crustal structure of the Cantabrian Mountains and Duero basin, J. Geophys. Res., 105(B2), 3001-3018, 2000.

Gallart, J., E. Banda, and M. Daignières, Crustal structure of the Paleozoic Axial Zone of the Pyrenees and transition to the North Pyrenean Zone, Ann. Geophys., 37(3), 457-480, 1981

Gallart, J., G. Fernández-Viejo, J. Díaz, N. Vidal, and J. A. Pulgar, Deep structure of the transition between the Cantabrian Mountains and the north Iberian Margin from wide-angle ESCI-N data, Rev. Soc. Geol. Esp., 8(4), 365-382, 1997.

Gallastegui, J., Estructura cortical de la Cordillera y Margen Continental Cantábricos: Perfiles ESCI-N, Trabajos Geol., Univ. Oviedo, 22, 9-231, 2000.

García-Mondéjar, J., Strike-slip subsidence of the Basque-Cantabrian Basin of northern Spain and its relationship to Aptian-Albian opening of Bay of Biscay, in Extensional Tectonics and Stratigraphy of the North Atlantic Margins, edited by A. J. Tankard and H. R. Balkwill, Mem. AAPG, 46, 395-409, 1989

Golberg, J. M., and H. Maluski, Données nouvelles et mise au point sur l'âge du métamorphisme pyrénéen, C. R. Acad. Sci., Ser. II, 306, 429$435,1988$.

Grandjean, G., Étude des structures crustales dans une portion de chaîne et de leur relation avec les bassins sédimentaires: Application aux Pyrénées occidentals, Bull. Cent. Rech. Explor. Prod. Elf Aquitaine, 18, 391-420, 1994.

Grandjean, G., C. Mennéchet, N. Debéglia, and D. Bonijoly, Insuring the quality of gravity data, Eos Trans. $A G U, 79(18), 217,221,1998$.

Julivert, M., Place de la chaîne Hercynienne des Pyrénées dans le cadre Varisque, in Synthèse Géologique et Géophysique des Pyrénées, vol. 1, Introduction: Géophysique, Cycle Hercynien, edited by A. Barnolas, J. C. Chiron, and B. Guérangé, pp. 586-587, Inst. Geol. y Miner. de Esp., Madrid, 1996

Julivert, M., and F. J. Martínez, Estructura de conjunto y visión global de la Cordillera Herciniana, in Libro Jubilar J. M. Ríos: Geología de España, vol. 1, pp. 612-630, Inst. Geol. y Miner. de Esp., Madrid, 1983.

Julivert, M., J. M. Fontboté, A. Ribeiro, and L. E. Conde, Mapa Tectónico de la Península Ibérica y Baleares: Memoria Explicativa, 113 pp., Inst. Geol. y Miner. de Esp., Madrid, 1974.

Lepvrier, C., and E. Martínez-García, Fault development and stress evolution of the post-Hercynian Asturian Basin (Asturias and Cantabria, northwest Spain), Tectonophysics, 184, 345-356, 1990.

Martínez-García, E., El pérmico de la región Cantábrica, in Carbonífero y Pérmico de España, edited by C. Martínez Díaz, pp. 391-402, Inst. Geol. y Miner. de Esp., Madrid, 1983.

Matte, P., Accretionary history and crustal evolution of the Variscan belt in western Europe, Tectonophysics, 196, 309-337, 1991.

Montigny, R., B. Azambre, M. Rossy, and R. Thuizat, K-Ar study of Cretaceous magmatism and metamorphism in the Pyrenees: Age and length of rotation of the Iberian Peninsula, Tectonophysics, 129, $257-$ $273,1986$. 
Muñoz, J. A., Evolution of a continental collision belt: ECORS-Pyrenees crustal balanced cross-section, in Thrust Tectonics, edited by K. R. McClay, pp. 235-246, Chapman and Hall, New York, 1992

Parga Pondal, I., (Ed.), Mapa xeolóxico do macizo hespérico, in Publicacións da Area de Xeoloxía e Minería do Seminario de Estudos Galegos, Map 39.232-1982, 19 pp., scale 1:500,000, Castro, La Coruña, Spain, 1982.

Pedreira, D., Modelización gravimétrica y magnética en $2.75 \mathrm{D}$ del sector central de la Cordillera Cantábrica y su transición a la Cuenca del Duero, M.Sc. thesis, 80 pp., Univ. de Oviedo, Oviedo, Spain, 1998.

Pérez-Estaún, A., J. R. Martínez-Catalán, and F. Bastida, Crustal thickening and deformation sequence in the footwall to the suture of the Variscan Belt of northern Spain, Tectonophysics, 191, 243-253, 1991.

Pérez-Estaún, A., J. A. Pulgar, E. Banda, J. Alvarez-Marrón, and Seismic Study of the North Iberian Crust Group, Crustal structure of the external Variscides in northwest Spain from deep seismic reflection profiling, Tectonophysics, 232, 91-118, 1994.

Pulgar, J. A., J. Gallart, G. Fernández-Viejo, A. Pérez-Estaún, and J. Álvarez-Marrón, Seismic image of the Cantabrian Mountains in the western extension of the Pyrenees from integrated ESCIN reflection and refraction data, Tectonophysics, 264, 1-19, 1996.

Pulgar, J. A., A. Pérez-Estaún, J. Gallart, J. Alvarez-Marrón, J. Gallastegui, J. L. Alonso, and the Seismic Study of the North Iberian Crust Group, The ESCI-N2 deep seismic reflection profile: A traverse across the Cantabrian Mountains and adjacent Duero basin, Rev. Soc. Geol. Esp., 8(4), $383-394,1997$.
Rat, P., The Basque-Cantabrian basin between the Iberian and European plates: Some facts but still many problems, Rev. Soc. Geol. Esp., 1(3-4), $327-348,1988$

Salas, R., and A. Casas, Mesozoic extensional tectonics, stratigraphy, and crustal evolution durwing the Alpine cycle of the eastern Iberian basin, Tectonophysics, 228, 33-55, 1993.

Teixell, A., Crustal structure and orogenic material budget in the west central Pyrenees, Tectonics, 17(3), 395-406, 1998.

Vergés, J., H. Millán, E. Roca, J. A. Muñoz, M. Marzo, J. Cirés, T. Den Bezemer, R. Zoetemeijer, and S. Cloetingh, Eastern Pyrenees and related foreland basins: Pre-, syn-, and post-collisional crustal-scale cross-sections, Mar. Pet. Geol., 12(8), 893-915, 1995.

Zelt, C. A., and R. B. Smith, Seismic traveltime inversion for 2-d crustal velocity structure, Geophys. J. Int., 108, 16-34, 1992.

J. Díaz and J. Gallart, Departament de Geofísica, Institut de Ciències de la Terra Jaume Almera, Consejo Superior de Investigaciones Científicas, c/Solé Sabarís, E-08028 Barcelona, Spain. (jdiaz@ija.csic.es; jgallart@ija. csic.es)

D. Pedreira and J. A. Pulgar, Departamento de Geología, Universidad de Oviedo, J. Arias de Velasco, s/n, E-33005 Oviedo, Spain. (david@geol. uniovi.es; pulgar@geol.uniovi.es) 